\title{
Disinfectant natural rubber films filled with modified zinc oxide nanoparticles: Synergetic effect of mechanical and antibacterial properties
}

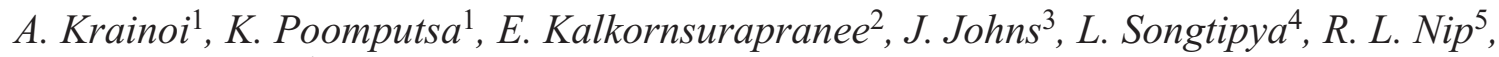 \\ Y. Nakaramontri ${ }^{6 *}$
}

${ }^{1}$ School of Bioresources and Technology, King Mongkut's University of Technology Thonburi, Bangkok, Thailand ${ }^{2}$ Faculty of Science, Prince of Songkla University, Hat Yai Campus, Songkhla, Thailand

${ }^{3}$ Department of Physics, Rajarajeswari College of Engineering, Bangalore, India

${ }^{4}$ Center of Excellence in Bio-Based Materials and Packaging Innovation, Faculty of Agro-Industry, Prince of Songkla University, Hat Yai Campus, Songkhla, Thailand

${ }^{5}$ Global Chemical Co., Ltd. Bangpoo Industrial Estate, Samutprakarn, Thailand

${ }^{6}$ Sustainable Polymer \& Innovative Composite Materials Research Group, Department of Chemistry, King Mongkut's

University of Technology Thonburi, Bangkok, Thailand

Received 10 May 2021; accepted in revised form 8 July 2021

\begin{abstract}
Disinfectant natural rubber (NR) film filled with nano-zinc oxide $\left(\mathrm{ZnO}_{\mathrm{np}}\right)$ was prepared via latex processes. In addition, modification of $\mathrm{ZnO}_{n p}$ was done by coating calcium carbonate $\left(\mathrm{CaCO}_{3}\right)$ at the ratios of 90:10 and 60:40 $\left(\mathrm{ZnO}_{\mathrm{np}}-\mathrm{Ca}_{10}\right.$ and $\mathrm{ZnO}_{\mathrm{np}}-\mathrm{Ca}_{40}$ ). Mechanical and thermo-mechanical properties, together with the unique anti-microbial activity of the resulting NR film products, were studied in detail. It was found that the nature of $\mathrm{ZnO}$ dispersion plays an important role in the improvement of the properties of NR films. Enhancement in the properties of NR was noticed for the films by the addition of $\mathrm{ZnO}_{\mathrm{np}}-\mathrm{Ca}_{10}$ and a reduction in properties was observed in the case of unmodified $\mathrm{ZnO}_{\mathrm{np}}$. Van-der Waals force of attraction among the $\mathrm{ZnO}_{\mathrm{np}}$ particles and the improved degree of crosslinking of NR molecules are the reasons for the property enhancement. The results are well correlated with qualitative and quantitative determinations against gram-negative E. coli anti-microbial studies. Usage of modified- $\mathrm{ZnO}_{\mathrm{np}}$ effectively kills bacteria through the formation of $\mathrm{ROS}$ and $\mathrm{Zn}^{++}$, which transfer across the NR molecules via electrostatic forces. Hence, it can be effectively used in the dipping process to develop gloves, condoms, clothes etc.
\end{abstract}

Keywords: nanocomposites, rubber, material testing, mechanical properties, anti-microbial properties

\section{Introduction}

Natural rubber (NR) is a widely used material in various industrial applications. Due to its excellent elasticity and mechanical properties, NR has been used in the manufacturing of tires, sports articles, sealing materials, gloves, rubber boots, and dairy rubber items [1]. In order to reach the specific properties of products, the addition of several fillers such as carbon black, silica and clay were incorporated. Fillers affect the intrinsic properties of NR significantly;
- Changes the insulating NR to a conducting elastomer for electronic devices [2-5],

- Increases abrasion resistance and wet traction of NR used in car tires [6-9],

- Improves the hydrophilic nature of NR used as organic substrates $[10,11]$.

NR has been used in various fields, but it is not suitable for medical applications due to its allergenic nature and inability to disinfect the microorganism. Hence, the anti-microbial property of NR has to be

"Corresponding author, e-mail: yeampon.nak@kmutt.ac.th C BME-PT 
improved by incorporating inorganic particles with high surface area in contact with NR matrix. This can be achieved by the incorporation of several nano-particles such as silver (AgNP) [12-14], titanium dioxide $\left(\mathrm{TiO}_{2}\right)[15,16]$, and zinc oxide $(\mathrm{ZnO})$ [17-22] to disinfect microbes such as E. coli, Staphylococcus aureus, Salmonella typhus, Pseudomonas sp, Salmonella sp., Shigella sp, K. pneumonia etc. The investigation was initiated by loading AgNP in thermoplastic low-density polyethylene (LDPE) and polypropylene (PP) as anti-microbial composite films against $E$. coli and $S$. aureus, which showed a $99.9 \%$ decrease in the number of viable bacteria [23]. Similarly, polysulfone membranes (PSf) containing AgNP exhibited a decrease of $90 \%$ Escherichia coli adhered cells compared to the pure PSf [24]. However, it was found that the disinfecting efficiency of the composites has strongly related to the nature of dispersion of AgNP, which cannot be easily controlled due to its high surface area and strong Vander Waals force of attraction among AgNP, resulting in agglomeration during film preparation [25]. Also, AgNP is toxic and harmful to humans on a short/long-term exposure owing to oxidative and inflammatory infections [26]. Therefore, the usage of AgNP should be minimized.

$\mathrm{ZnO}$ nanoparticle was found to be an inorganic metal oxide to replace the toxic AgNP. It is a nontoxic metal oxide and also a safe anti-microbial agent generally used in medical devices and preservative packaging applications [27]. In addition, $\mathrm{ZnO}$ is recognized as a multi-functional material to fabricate polymer nanocomposite with exceptional electrical, optical, thermal, mechanical, catalytic, and biomedical properties [28]. ZnO can distort and damage the surface of bacterial cells, bringing about spillage of intracellular substances and finally removes the bacterial cells [28]. It was found that $\mathrm{ZnO}$ effectively reacts with light and moisture and consequently produces hydrogen peroxide $\left(\mathrm{H}_{2} \mathrm{O}_{2}\right)$ to kill bacteria [17]. $\mathrm{ZnO}$ dispersed in poly(ether ether ketone) (PEEK) showed superior antibacterial activity against both Gramnegative Escherichia coli and Gram-positive Staphylococcus aureus bacteria [29]. Incorporating $\mathrm{ZnO}$ into natural polymers such as $\mathrm{ZnO}$-based natural rubber (NR) foam was assessed by S. aureus and E. coli antibacterial vulnerability tests. The study on the antibacterial activity of the foam composites revealed that the activity of nano-sized $\mathrm{ZnO}$ has been extended to the NR foam [30]. This causes several advantages to the NR foam products. This technology can also be applied for the preparation of NR film by the addition of nano- and micro- $\mathrm{ZnO}$ in pre-vulcanized NR latex. The result clearly showed the effectiveness in antifungal activity of the film with nano- $\mathrm{ZnO}$ compared to the one with micro- $\mathrm{ZnO}$ at the same concentration [31]. However, the use of $\mathrm{ZnO}$ in NR for performing disinfection is still challenging since it is difficult to disperse $\mathrm{ZnO}$ in the hydrophobic NR matrix. Therefore, study in this area is limited and most of the NR film products exhibit poor ability to resist bacterial and micro-organism. When considering $\mathrm{ZnO}$ reinforced into $\mathrm{NR}$, it can be used as an activator in NR products by reacting with stearic acid to form zinc stearate, which effectively propagates crosslinking among the NR molecules [32]. This means that the use of $\mathrm{ZnO}$ in NR film acts as both an activator and anti-microbial agent. However, the formation of bonds of $\mathrm{Zn}-\mathrm{O}-\mathrm{Zn}$ among particles results in strong agglomeration of $\mathrm{ZnO}$ [33], which reduces the properties of $\mathrm{ZnO}$-filled NR, and the modification of $\mathrm{ZnO}$ might be needed to avoid agglomeration.

Therefore, in the present work, $\mathrm{ZnO}$ incorporated NR composites were prepared by varying the loading levels of 0-7 phr. In addition, the variation of properties of NR on the particle size, surface area, and doses of $\mathrm{ZnO}$ was investigated for different types of $\mathrm{ZnO}$. White seal $\mathrm{ZnO}\left(\mathrm{ZnO}_{\mathrm{ws}}\right), \mathrm{ZnO}$ nanoparticles $\left(\mathrm{ZnO}_{\mathrm{np}}\right)$ and $\mathrm{ZnO}_{\mathrm{np}}$-coated with $\mathrm{CaCO}_{3}\left(\mathrm{ZnO}_{\mathrm{np}}-\mathrm{CaCO}_{3}\right)$ at the \%weight ratios of 90:10 and 60:40 ( $\left.\mathrm{ZnO}: \mathrm{CaCO}_{3}\right)$ were incorporated into NR. The modification of $\mathrm{ZnO}_{\mathrm{np}}$ with $\mathrm{CaCO}_{3}$ aims to improve the dispersion of $\mathrm{ZnO}_{\mathrm{np}}$ inside the NR matrix in order to enhance crosslinking propagation of NR molecules and also the disinfection degree of the film. Mechanical and dynamical properties, thermo-mechanical properties, thermal stability, and biological testing of the resulting composites were investigated. The main aim of this work is to develop new medical disinfection goods to be used as rubber-glove, shoes, masks, and personal protective equipment (PPE) with NR as the main component. Also, the disinfection nature of these $\mathrm{ZnO}$ particles was elucidated at different degrees of loading throughout the NR matrix. Modification of $\mathrm{ZnO}_{\mathrm{np}}$ with $\mathrm{CaCO}_{3}$ was minimized the cost of additives effectively since it reduces the purity of $\mathrm{ZnO}_{\mathrm{np}}$ and significantly improves the properties. 


\section{Experimental}

\subsection{Materials}

Natural rubber (NR) latex with high ammonia concentration was manufactured by Chalong Latex Industry Co., Ltd. (Songkhla, Thailand). Various types of $\mathrm{ZnO}$ particles used in this work are as shown in Table 1, including $\mathrm{ZnO}_{\text {wp }}$ (white seal grade) together with different types of $\mathrm{ZnO}$ nanoparticles (i.e., $\mathrm{ZnO}_{\mathrm{np}}$ and $\mathrm{ZnO}$-adsorbed $\mathrm{CaCO}_{3}$ at the ratios 90:10 $\left(\mathrm{ZnO}_{\mathrm{np}}-\mathrm{Ca}_{10}\right)$ and 60:40 $\left.\left(\mathrm{ZnO}_{\mathrm{np}}-\mathrm{Ca}_{40}\right)\right)$. All $\mathrm{ZnO}_{\mathrm{np}}$ were produced through wet preparation processes [34] and supplied by Global Chemical Co., Ltd. (Samut Prakan, Thailand). In addition, the potassium hydroxide was manufactured by Qingdao Hisea Chem Co. Ltd., (Qingdao, China). Potassium Laurate, $50 \%$ zinc diethyldithiocarbamate (ZDEC), 50\% poly(dicyclopentadiene-co-p-cresol), and $50 \%$ sulfur were supplied by Thanodom Trading Co. Ltd. (Bangkok, Thailand).

\subsection{Preparation of $\mathrm{NR} / \mathrm{ZnO}$ composite films}

NR latex was compounded according to the formulation shown in Table 2. The compounding process was initiated by the addition of specific chemicals (Table 1) into NR latex using a mechanical stirrer at

Table 1. Specification of each $\mathrm{ZnO}$ used in the present study provided directly by Global Chemical Co., Ltd. using BET analysis.

\begin{tabular}{|l|c|c|}
\hline \multicolumn{1}{|c|}{ Ingredients } & $\begin{array}{c}\text { ZnO content } \\
{[\%]}\end{array}$ & $\begin{array}{c}\text { Specific surface area } \\
{\left[\mathbf{m}^{2} / \mathbf{g}\right]}\end{array}$ \\
\hline $\mathrm{ZnO}_{\mathrm{ws}}$ & 99.50 & 5 \\
\hline $\mathrm{ZnO}_{\mathrm{np}}$ & 97.83 & 40 \\
\hline $\mathrm{ZnO}_{\mathrm{np}}-\mathrm{Ca}_{10}$ & 91.39 & 40 \\
\hline $\mathrm{ZnO}_{\mathrm{np}}-\mathrm{Ca}_{40}$ & 60.92 & 40 \\
\hline
\end{tabular}

Table 2. Formulation for NR latex compound with different types of $\mathrm{ZnO}$.

\begin{tabular}{|l|c|}
\hline \multicolumn{1}{|c|}{ Ingredients } & $\begin{array}{c}\text { Contents } \\
\text { [phr] }\end{array}$ \\
\hline $60 \%$ NR latex & 100 \\
\hline $20 \%$ Potassium Laurate & 1.00 \\
\hline $10 \%$ Potassium hydroxide & 0.25 \\
\hline $50 \%$ Zinc diethyldithiocarbamate (ZDEC) & 1.25 \\
\hline $50 \%$ Poly(dicyclopentadiene-co-p-cresol) & 1.00 \\
\hline $50 \%$ Sulfur & 2.00 \\
\hline $25 \% \mathrm{ZnO}_{\mathrm{ws}}$ & \multirow{2}{*}{$0,3,5,7$} \\
\hline $25 \% \mathrm{ZnO}_{\mathrm{np}}$ & \\
\hline $25 \% \mathrm{ZnO}_{\mathrm{np}}-\mathrm{Ca}_{10}$ & \\
\hline $25 \% \mathrm{ZnO}_{\mathrm{np}}-\mathrm{Ca}_{40}$ & \\
\hline
\end{tabular}

$150 \mathrm{rpm}$. The mixing was continued at room temperature for $24 \mathrm{~h}$ the so-called maturation of NR latex compound. Thereafter, the NR/ZnO composite films were prepared by using the latex mixing method, and the ingredients are as shown in Table 2. The mixing process was started by stirring the latex compound for $3 \mathrm{~min}$ before the addition of $\mathrm{ZnO}$. Mixing was continued for another 10 min and dipped a glass plate inside the latex compound for $10 \mathrm{~s}$ to get the films with a thickness of approximately $1.0-1.5 \mathrm{~mm}$. Samples were eventually dried at $70^{\circ} \mathrm{C}$ for $24 \mathrm{~h}$ to form the $\mathrm{NR} / \mathrm{ZnO}$ composite films. It is noted that, during the drying propagation for $25 \%$ of cure time, the sample was again dipped into a $5 \mathrm{wt} \% \mathrm{ZnO}$ dispersion with controlled dipping times periodically up to $24 \mathrm{~h}$. Finally, the films were removed from the mold, washed with distilled water, and kept in the desiccator. The total $\mathrm{ZnO}$ concentrations were controlled at 3,5, and $7 \mathrm{phr}$ after the cleaning process of the samples through \%weight evaluation. Thus, only $90 \%$ of $\mathrm{ZnO}$ was added in each individual formulation during compounding. Another $10 \%$ was incorporated eventually before performing the test. It is noted that all the composite films were labeled as $\mathrm{NR} /$ normal $\mathrm{ZnO}, \mathrm{NR} / \mathrm{ZnO}_{\mathrm{np}}, \mathrm{NR} / \mathrm{ZnO}_{\mathrm{np}}-\mathrm{Ca}_{10}$, and $\mathrm{NR} / \mathrm{ZnO}_{\mathrm{np}}-\mathrm{Ca}_{40}$ for the NR composites filled with normal $\mathrm{ZnO}, \mathrm{ZnO}$ nanoparticle, and $\mathrm{ZnO}_{\mathrm{np}}$-coated $\mathrm{CaCO}_{3}$ at $\mathrm{ZnO}: \mathrm{CaCO}_{3}$ ratios of $90: 10$ and $60: 40$, respectively.

\section{Characterizations}

\subsection{Particle size analyzer}

$\mathrm{ZnO}_{\mathrm{ws}}, \mathrm{ZnO}_{\mathrm{np}}, \mathrm{ZnO}_{\mathrm{np}}-\mathrm{Ca}_{10}$, and $\mathrm{ZnO}_{\mathrm{np}}-\mathrm{Ca}_{40}$ were initially dispersed in deionized water at $0.5 \mathrm{wt} \%$. The suspension of each $\mathrm{ZnO}$ was evaluated by using the dynamic light scattering (DLS) technique with the help of a nanoparticle analyzer, SZ-100 series (HORIBA Instruments (Singapore) Pvt Ltd, Changi Business Park Vista, Singapore).

\subsection{Mechanical properties}

Mechanical properties of pure NR and NR composites filled with different types of $\mathrm{ZnO}$ were investigated using a universal tensile testing machine (Tinius Olsen model 1 ST, Tinius Olsen, Co., Ltd., Salfords, UK). The tests were carried out with a cross-head speed of $500 \mathrm{~mm} / \mathrm{min}$ at room temperature, according to ISO 37. 


\subsection{Crosslink density}

Crosslink densities of samples were determined from swelling experiments in toluene. The samples with dimension $(10 \times 10 \times 2) \mathrm{mm}^{3}$ were prepared and weighted before immersing into toluene under ambient conditions for seven days following the ASTM D471-79. The swollen samples were then removed, and the excess liquid on the surface was removed by blotting with filter paper. These specimens were dried in a hot air oven at $60^{\circ} \mathrm{C}$ until attaining a constant weight. The final weight was then compared with the original weight, and the apparent crosslink density was eventually calculated using the Flory-Rehner equation (Equation (1)) [35]:

$v=\frac{-\left(\ln \left(1-\phi_{\rho}\right)+\phi_{\rho}+\chi \phi_{\rho}^{2}\right)}{V_{i}\left(\phi_{\rho}^{1 / 3}-\phi_{\rho / 2}\right)}$

where $v$ is the crosslink density $\left[\mathrm{mol} / \mathrm{m}^{3}\right], \phi_{\rho}$ is the volume fraction of rubber in a swollen network, $V_{1}$ refers to the molar volume of toluene, and $\chi$ is the Flory-Huggins interaction parameter $(0.4)$ between toluene and NR [36].

\subsection{Temperature scanning stress relaxation (TSSR)}

Stress relaxation of pure $\mathrm{NR}, \mathrm{NR} / \mathrm{ZnO}_{\mathrm{ws}}, \mathrm{NR} / \mathrm{ZnO}_{\mathrm{np}}$, $\mathrm{NR} / \mathrm{ZnO}_{\mathrm{np}}-\mathrm{Ca}_{10}$, and $\mathrm{ZnO}_{\mathrm{np}}-\mathrm{Ca}_{40}$ was investigated with a TSSR meter (Brabender GmbH \& Co. KG, Duisburg, Germany). The dumbbell-shaped specimens were first prepared according to ISO 527, type $5 \mathrm{~A}$. The specimens were annealed at $100^{\circ} \mathrm{C}$ for $30 \mathrm{~min}$, cooled down to room temperature, and conditioned for about $30 \mathrm{~min}$ before testing. This was to avoid interference from the storage hardening of NR due to non-rubber constituents [37]. The test was performed by extending the sample at a constant strain of $50 \%$ and conditioning at $23^{\circ} \mathrm{C}$ for $2 \mathrm{~h}$. Then, the non-isothermal test was performed by raising the temperature from 23 to $220^{\circ} \mathrm{C}$ at a constant heating rate of $2{ }^{\circ} \mathrm{C} / \mathrm{min}$. The observed results were used to explain the relationship between stress relaxation and relaxation spectrum as a function of temperature.

\subsection{Thermogravimetric analysis (TGA)}

Thermal analysis of pure NR and its composites was performed by using thermogravimetric analyzer TGA STA8000 (Perkin Elmer, Ohio, USA). The measurement was carried out under nitrogen atmosphere in the temperature range of 30 to $600^{\circ} \mathrm{C}$ before switching to oxygen atmosphere with a holding time of $5 \mathrm{~min}$ and raised the temperature to $800^{\circ} \mathrm{C}$ at a heating rate of $10^{\circ} \mathrm{C} / \mathrm{min}$

\subsection{Morphologies}

The morphologies of unmodified and modified $\mathrm{ZnO}$ particles with $\mathrm{CaCO}_{3}$ were characterized with transmission electron microscope (TEM) model JEOL JEM-1400 (JEOL, Tokyo, Japan) using 80 kV accelerating voltage. In addition, morphological properties of the composites were studied by using optical microscopy (Carl Zeiss Microscopy GmbH, Oberkochen, Germany). Also, the high-resolution morphologies and the energy dispersive X-ray analysis (EDX) patterns of the composites were obtained from a scanning electron microscope (SEM) (Apreo, Thermo Fisher Scientific, Brno, Czech Republic). The samples were first cryogenically fractured in liquid nitrogen to create a new cross-sectional surface. Then, the surface was sputter-coated with a thin layer of gold under vacuum before scanning by SEM.

\subsection{Anti-microbial properties}

Anti-microbial properties of gum $\mathrm{NR}, \mathrm{NR} / \mathrm{ZnO}_{\mathrm{ws}}$, $\mathrm{NR} / \mathrm{ZnO}_{\mathrm{np}}, \mathrm{NR} / \mathrm{ZnO}_{\mathrm{np}}-\mathrm{Ca}_{10}$, and $\mathrm{ZnO}_{\mathrm{np}}-\mathrm{Ca}_{40}$ composites were characterized by means of qualitative and quantitative determinations. The qualitative determination was performed to observe the clear zone near the sample. First, Luria Broth medium was prepared, and a single colony of the Gram-negative E. coli bacteria was inoculated under aseptic conditions. Then, it was incubated at $37^{\circ} \mathrm{C}$ for $12 \mathrm{~h}$ in a mechanical shaker. Subsequently, $100 \mu \mathrm{l}$ of a $10^{8} \mathrm{cfu} / \mathrm{ml}$ bacteria suspension was spread onto agar plates. Then, gum NR and its composites were cut in circular shape with a diameter of $6 \mathrm{~mm}$ and sterilized by $70 \%$ ethanol. The samples were eventually placed onto agar plates and aerobically incubated at $37^{\circ} \mathrm{C}$ for $24 \mathrm{~h}$ in an incubator. The diameter of the zone of inhibition can be measured and reported on a centimeter scale [30].

The quantitative determination was carried out by optical density with a spectrophotometer (Thermo Fisher Scientific Genesys 20 (4001/4) Spectrophotometer, Apeldoorn, Netherlands) at 600 nanometer wavelength. In addition, the initial bacteria suspension of $E$. coli was prepared at an optical density of $0.2\left(O D_{600}=0.2\right)$. The samples of gum NR, NR/ $\mathrm{ZnO}_{\mathrm{ws}}, \mathrm{NR} / \mathrm{ZnO}_{\mathrm{np}}, \mathrm{NR} / \mathrm{ZnO}_{\mathrm{np}}-\mathrm{Ca}_{10}$, and $\mathrm{NR} / \mathrm{ZnO}_{\mathrm{np}}{ }^{-}$ $\mathrm{Ca}_{40}$ composites were prepared with a dimension of 
$10 \times 10 \mathrm{~mm}^{2}$. Consequently, the samples were placed in a $50 \mathrm{ml}$ tube of bacteria suspension and then incubated at $37^{\circ} \mathrm{C}$ in a mechanical shaker for 1,2 , and $4 \mathrm{~h}$ for optical density testing by spectrophotometer.

\section{Result and discussion}

\subsection{Effect of modification of $\mathrm{ZnO}$ on the observed particle size}

Figure 1 shows the particle size distribution of $\mathrm{ZnO}_{\mathrm{ws}}$, $\mathrm{ZnO}_{\mathrm{np}}, \mathrm{ZnO}_{\mathrm{np}}-\mathrm{Ca}_{10}$, and $\mathrm{ZnO}_{\mathrm{np}}-\mathrm{Ca}_{40}$ obtained from the particle analyzer. It is observed that the polydispersity index (PDI) of $\mathrm{ZnO}_{\mathrm{ws}}$ is 0.336 , while the

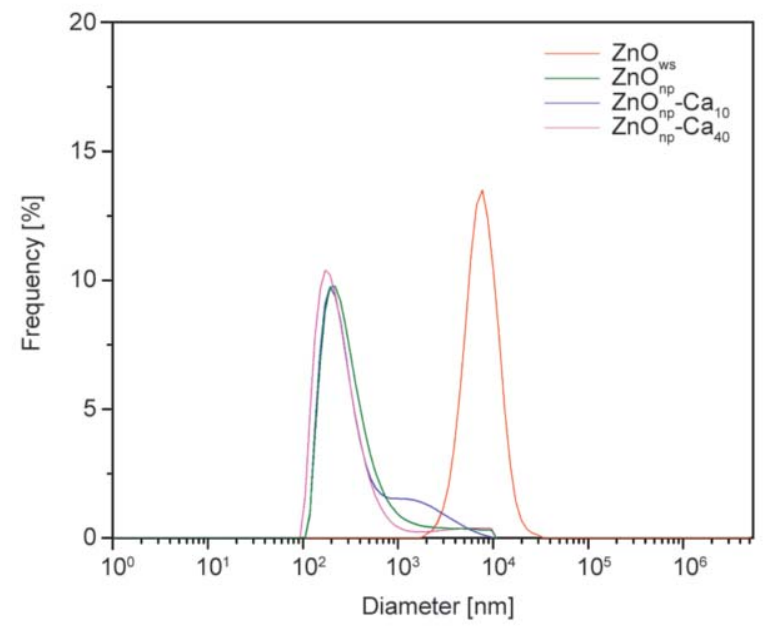

Figure 1. Particle size distribution of $\mathrm{ZnO}_{\mathrm{ws}}, \mathrm{ZnO}_{\mathrm{np}}, \mathrm{ZnO}_{\mathrm{np}}{ }^{-}$ $\mathrm{Ca}_{10}$ and $\mathrm{ZnO}_{n p}-\mathrm{Ca}_{40}$.

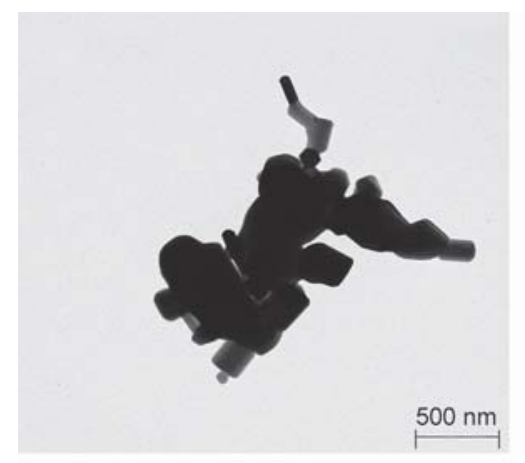

a)

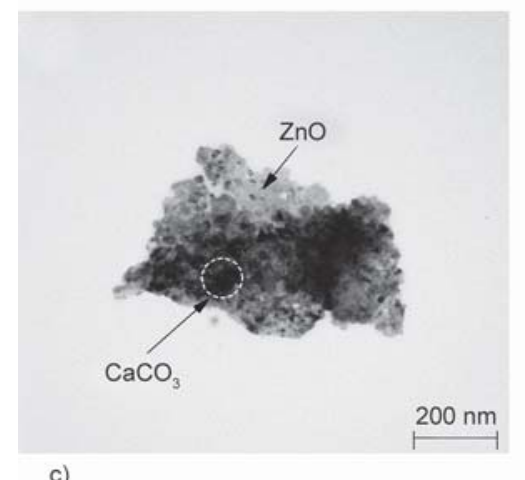

c) values of $\mathrm{ZnO}_{\mathrm{np}}-\mathrm{Ca}_{10}, \mathrm{ZnO}_{\mathrm{np}}-\mathrm{Ca}_{40}$, and $\mathrm{ZnO}_{\mathrm{np}}$ are found to be $0.355,0.354$, and 0.335 , respectively. This reveals that all samples provided a narrow range of particle size distribution, indicated better dispersion of particles. In addition, the histogram shows the particle size ranges from 2 to $20 \mu \mathrm{m}$ for $\mathrm{ZnO}_{\mathrm{ws}}$. It is also found that the $\mathrm{ZnO}_{\mathrm{np}}, \mathrm{ZnO}_{\mathrm{np}}-\mathrm{Ca}_{10}$, and $\mathrm{ZnO}_{\mathrm{np}}-\mathrm{Ca}_{40}$ showed particle size in the range of 100 to $1000 \mathrm{~nm}$. This confirms the smaller particle sizes of $\mathrm{ZnO}_{\mathrm{np}}$ than the normal one. It is also seen in Figure 1 that the largest particle is observed in $\mathrm{ZnO}_{\mathrm{ws}}$ with an average particle size of $7.697 \mu \mathrm{m}$. However, $\mathrm{ZnO}_{\mathrm{np}}-\mathrm{Ca}_{10}, \mathrm{ZnO}_{\mathrm{np}}-\mathrm{Ca}_{40}$, and $\mathrm{ZnO}_{\mathrm{np}}$ exhibited smaller average particle size than that of $\mathrm{ZnO}_{\mathrm{ws}}$ at 193.48, 171.25 , and $218.6 \mathrm{~nm}$, respectively. Additionally, $\mathrm{ZnO}_{\mathrm{np}}-\mathrm{Ca}_{40}$ exhibited the smallest average particle size when compared to $\mathrm{ZnO}_{\mathrm{np}}-\mathrm{Ca}_{10}$ and $\mathrm{ZnO}_{\mathrm{np}}$. It is clearly seen that the modification of $\mathrm{ZnO}$ by absorbing $\mathrm{CaCO}_{3}$ reduces the average particle sizes of $\mathrm{ZnO}_{\mathrm{np}}$, and this can be the reason for better dispersion of $\mathrm{ZnO}_{\mathrm{np}}$ throughout the NR matrix during preparation. These results are comparable with the TEM images of $\mathrm{ZnO}_{\text {ws }}$ (Figure 2a) and $\mathrm{ZnO}_{\text {np }}$ particles, which show $\mathrm{ZnO}$ aggregates as represented in Figure 2. It is clearly seen that the size of $\mathrm{ZnO}_{\mathrm{np}}$ (Figure $2 \mathrm{~b}$ ) reduces upon its modification with $\mathrm{CaCO}_{3}$ as well as on increasing the concentration of $\mathrm{CaCO}_{3}$ (Figures 2c, 2d).

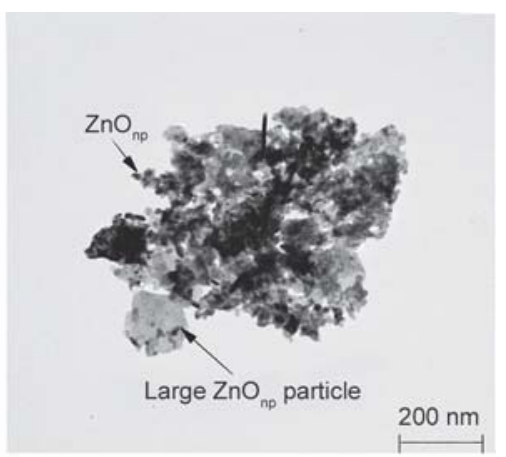

b)

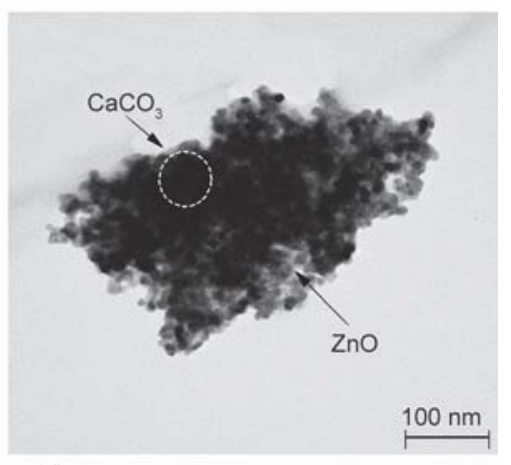

d)

Figure 2. TEM images of $\mathrm{ZnO}_{\mathrm{ws}}$ (a), $\mathrm{ZnO}_{\mathrm{np}}$ (b), $\mathrm{ZnO}_{\mathrm{np}}-\mathrm{Ca}_{10}$ (c) and $\mathrm{ZnO}_{\mathrm{np}}-\mathrm{Ca}_{40}$ (d). 


\subsection{Relation between mechanical properties and apparent crosslink density}

Figure 3 shows stress-strain curves of NR films filled with $\mathrm{ZnO}_{\mathrm{ws}}, \mathrm{ZnO}_{\mathrm{np}}, \mathrm{ZnO}_{\mathrm{np}}-\mathrm{Ca}_{10}$, and $\mathrm{ZnO}_{\mathrm{np}}-\mathrm{Ca}_{40}$. Also, the details of $100 \%$ moduli, tensile strength, and elongation at break are summarized in Figure 3. A considerable change in the stress-strain curves is observed after the addition of $\mathrm{ZnO}$, as shown in Figure 3a. This relates to the strain-induced crystallization (SIC) behavior of the vulcanizates by increasing the crosslink density of the NR matrix. Thus, the slope $(m)$ of the curve is significantly increased due to the presence of $\mathrm{ZnO}$. On comparing the types of $\mathrm{ZnO}, \mathrm{ZnO}_{\mathrm{np}}$ showed the lowest SIC of 0.03364 , which might be owing to the degree of $\mathrm{ZnO}_{\mathrm{np}}$ agglomeration and related to its high surface area, increasing the opportunity of $\mathrm{ZnO}$ to contact together rather than react with the NR compounds. However, the agglomeration of $\mathrm{ZnO}_{\mathrm{np}}$ is reduced by the coating of $\mathrm{CaCO}_{3}$ on $\mathrm{ZnO}_{n p}$, and it leads to an increase in the slope to 0.09226 and 0.08446 for $\mathrm{ZnO}_{\mathrm{np}}-\mathrm{Ca}_{10}$ and $\mathrm{ZnO}_{\mathrm{np}}-\mathrm{Ca}_{40}$, respectively. Considering Figure 3b, it is obviously seen that the tensile properties of the gum NR are significantly increased upon the addition of all types of $\mathrm{ZnO}$ enhances the crosslinking ability by the activation of $\mathrm{ZnO}$ inside the NR matrix.
As seen in Figure 3a, the vulcanizate with $\mathrm{ZnO}_{\mathrm{np}}$ exhibited a strong reduction of tensile strength compared to other types of $\mathrm{ZnO}$. However, concerning the addition of $\mathrm{ZnO}, \mathrm{ZnO}_{\mathrm{np}}-\mathrm{Ca}_{10}$, and $\mathrm{ZnO}_{\mathrm{np}}-\mathrm{Ca}_{40}$, a slight difference is observed in the tensile properties. Here, it is indicated that the highest tensile strength is observed after the modification of $\mathrm{ZnO}_{\mathrm{np}}$ with $\mathrm{CaCO}_{3}$ due to the improved $\mathrm{ZnO}$ dispersion inside the NR matrix, particularly the one filled with $\mathrm{ZnO}_{\mathrm{np}}$ $\mathrm{Ca}_{10}$. States of dispersion and distribution of each $\mathrm{ZnO}$ inside the $\mathrm{NR}$ vulcanizate based on the indication of tensile properties as displayed in the proposed model of Figure 4. Here, the large particle of $\mathrm{ZnO}_{\mathrm{ws}}$ has a low specific surface area leading to lower interaction between its particles which reduces particle agglomeration and also activates the vulcanization of the sulfur curing system (Figure $4 \mathrm{a}$ ). However, the lowest tensile strength observed in $\mathrm{NR} / \mathrm{ZnO}_{\mathrm{np}}$ vulcanizate is due to the small particle size in the order of nanometer, which generated high specific surface area and supported high Van der Waals force between particles, leading to agglomeration of $\mathrm{ZnO}_{\mathrm{np}}$ as observed in Figure $4 \mathrm{~b}$. However, for the one filled with modified $\mathrm{ZnO}_{\mathrm{np}}$, i.e., $\mathrm{ZnO}_{\mathrm{np}}-\mathrm{Ca}_{10}$ and $\mathrm{ZnO}_{\mathrm{np}}-$ $\mathrm{Ca}_{40}$, improved dispersion is observed due to the obstruction of Van der Waal force of attraction among

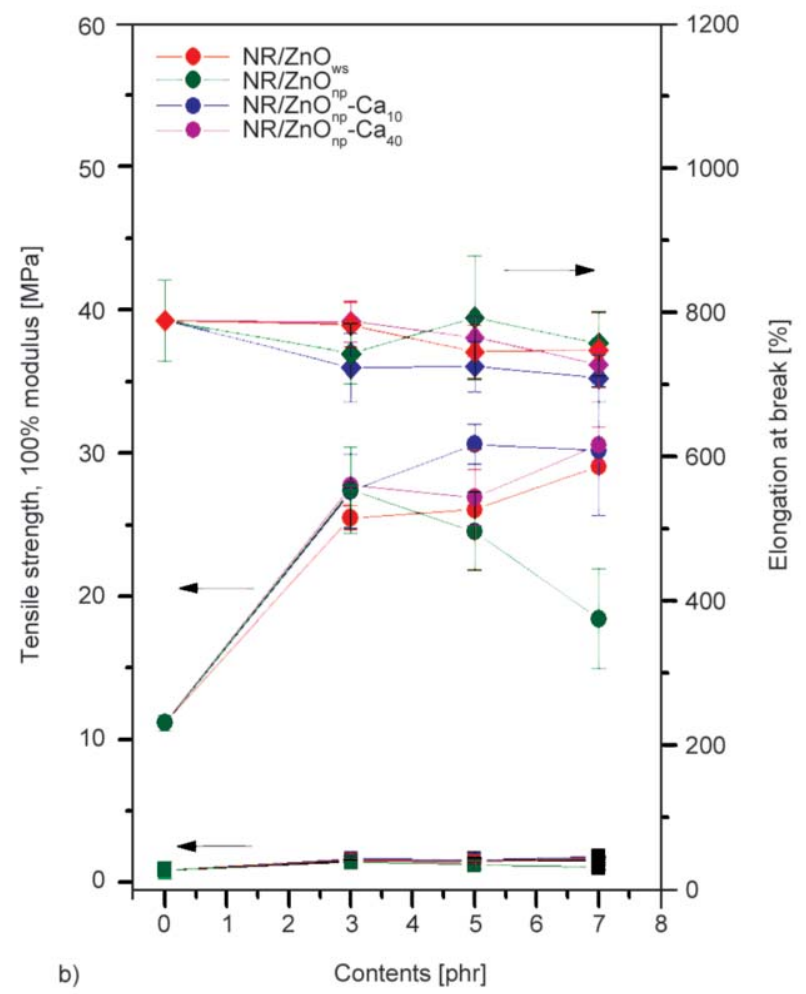

Figure 3. Stress-strain curves of $\mathrm{NR}$ films filled with $5 \mathrm{phr}$ of $\mathrm{ZnO}_{\mathrm{ws}}, \mathrm{ZnO}_{\mathrm{np}}, \mathrm{ZnO}_{\mathrm{np}}-\mathrm{Ca}_{10}$ and $\mathrm{ZnO}_{\mathrm{np}}-\mathrm{Ca}_{40}(\mathrm{a})$, and the observed tensile strength, 100\%modulus and elongation at break of NR films with 0, 3, 5 and $7 \mathrm{phr}$ of $\mathrm{ZnO}$ (b). 


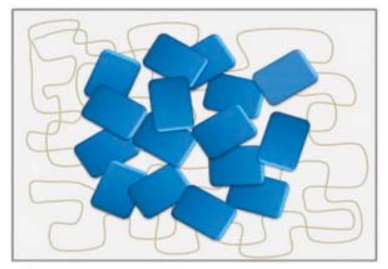

a)

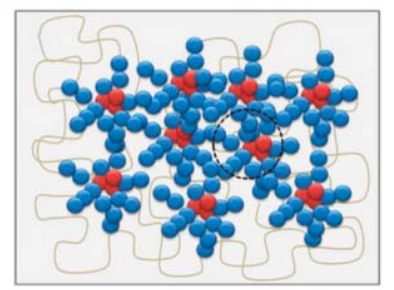

c)

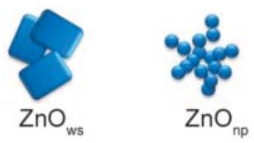

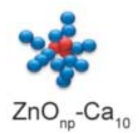

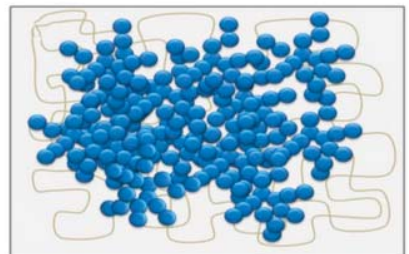

b)

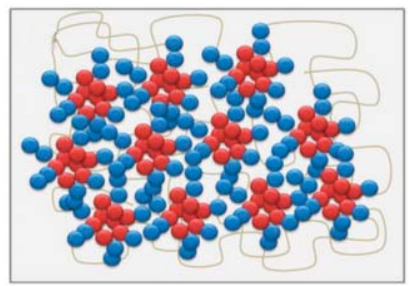

d)
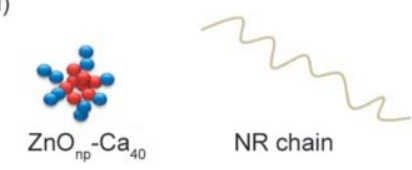

Figure 4. Proposed dispersion model of $\mathrm{NR}$ films filled with $\mathrm{ZnO}_{\mathrm{ws}}$ (a), $\mathrm{ZnO}_{\mathrm{np}}$ (b), $\mathrm{ZnO}_{\mathrm{np}}-\mathrm{Ca}_{10}$ (c) and $\mathrm{ZnO}_{\mathrm{np}}-\mathrm{Ca}_{40}$ (d).

$\mathrm{ZnO}_{n p}$ particles by the existence of $\mathrm{CaCO}_{3}$ [38]. It is also clearly observed in Figure 3 and as shown in the proposed model (Figures $4 \mathrm{c}$ and $4 \mathrm{~d}$ ). The excess $\mathrm{CaCO}_{3}$ of $40 \mathrm{wt} \%$ lowers the ability of crosslink formation in NR molecules and reduces the tensile strength of NR films filled with $\mathrm{ZnO}_{\mathrm{np}}-\mathrm{Ca}_{40}$ compared to $\mathrm{ZnO}_{\mathrm{np}}-\mathrm{Ca}_{10}$. Conversely, the values of moduli and elongation in the case of the films filled with different types of $\mathrm{ZnO}$, there is no considerable effect on the addition of $5 \mathrm{phr} \mathrm{ZnO}$ since the concentration is not high enough for providing reinforcement. Thus, the dispersion of $\mathrm{ZnO}$ and $\mathrm{ZnO}_{\mathrm{np}}$ is the key factor to exhibit different film properties according to the different free volumes inside the matrix. This can be explained by the tensile properties of vulcanizates, as shown in Figure $3 \mathrm{~b}$. It is noted that the increase of each $\mathrm{ZnO}$ up to $7 \mathrm{phr}$ does not change much in the tensile strength. However, a strong decrease in tensile performance is clearly observed in the case of $\mathrm{ZnO}_{\mathrm{np}}$ due to the strong $\mathrm{ZnO}$ agglomeration within the NR matrix.

It indicates that the tensile properties of NR vulcanizates are effectively related to the nature of dispersion of $\mathrm{ZnO}$ throughout the matrix since it controls the origination of crosslinking among NR molecules. In order to clarify the occurrence of crosslinking propagation in the vulcanizates, the reduced stress as a function of extension ratio is taken into account by using the Mooney-Rivlin equation (Equation (2)) [39], and the relation is plotted as shown in Figure 5.

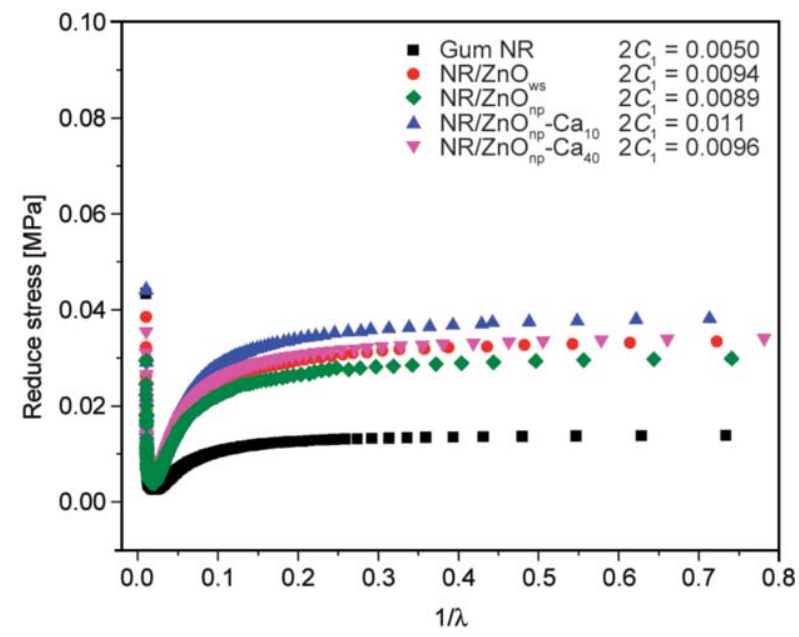

Figure 5. Mooney-Rivlin plot of $\mathrm{NR}$ films filled with $\mathrm{ZnO}_{\mathrm{ws}}$, $\mathrm{ZnO}_{\mathrm{np}}, \mathrm{ZnO}_{\mathrm{np}}-\mathrm{Ca}_{10}$ and $\mathrm{ZnO}_{\mathrm{np}}-\mathrm{Ca}_{40}$.

$\sigma^{*}=\frac{\sigma}{\lambda-\frac{1}{\lambda^{2}}}=2 C_{1}+\frac{2 C_{2}}{\lambda}$

where $\sigma$ and $\lambda$ are the stress and the extension ratio according to the tensile testing, respectively, whereas $C_{1}$ and $C_{2}$ are the parameters related to the crosslink density and entanglement of NR molecular chains, respectively. According to James and Guth approach, the reduced stress $\left(\sigma^{*}\right)$ refers to the elastic modulus, which is proportional to the crosslink density of the vulcanizates [39]. Thus, the crosslink density of each vulcanizate was fitted from Equation (2) corresponds to the observed $2 C_{1}$ in connection with the reduced stress as a function of the reciprocal of $\lambda$ in 
Table 3. Comparison of crosslink density determined from Mooney-Rivlin and Flory-Rehner equation.

\begin{tabular}{|l|c|c|}
\hline \multicolumn{1}{|c|}{ Samples } & $\begin{array}{c}\text { Mooney-Rivlin } \\
\text { equation }\end{array}$ & $\begin{array}{c}\text { Flory-Rehner equation } \\
{\left[\mathbf{m o l} / \mathbf{m}^{3}\right]}\end{array}$ \\
\hline $\mathrm{Gum} \mathrm{NR}$ & 0.0050 & 24.51 \\
\hline $\mathrm{NR} / \mathrm{ZnO}_{\mathrm{ws}}$ & 0.0094 & 58.58 \\
\hline $\mathrm{NR} / \mathrm{ZnO}_{\mathrm{np}}$ & 0.0089 & 50.62 \\
\hline $\mathrm{NR} / \mathrm{ZnO}_{\mathrm{np}}-\mathrm{Ca}_{10}$ & 0.0011 & 88.44 \\
\hline $\mathrm{NR} / \mathrm{ZnO}_{\mathrm{np}}-\mathrm{Ca}_{40}$ & 0.0096 & 65.14 \\
\hline
\end{tabular}

Figure 5. The observed crosslink density is in good agreement with the tensile properties, particularly the tensile strength of the vulcanizates. Here, the addition of all types of $\mathrm{ZnO}$ increases significantly the crosslinking of the NR matrix, while the highest value is noticed for the NR film filled with $\mathrm{ZnO}_{\mathrm{np}}-\mathrm{Ca}_{10}$. However, according to the agglomeration of $\mathrm{ZnO}_{\mathrm{np}}$, poor crosslinking propagation is found and leads to poor tensile properties, as shown in Figure 4 and Table 3.

Chemical crosslinks present in the NR vulcanizates filled with $\mathrm{ZnO}$ can also be evaluated by using the swelling method according to the Flory-Rehner equation. Figure 6 shows the crosslinking density of NR films, and a similar trend is observed as seen from the Mooney-Rivlin equation, and the crosslink density is found to be increased with the addition of $\mathrm{ZnO}$. Here, the gum NR exhibited the lowest crosslink density at $24.51 \mathrm{~mol} / \mathrm{m}^{3}$, whereas the addition of unmodified and modified $\mathrm{ZnO}$ increases crosslinking of the gum NR at approximately $100 \%$. As expected, this

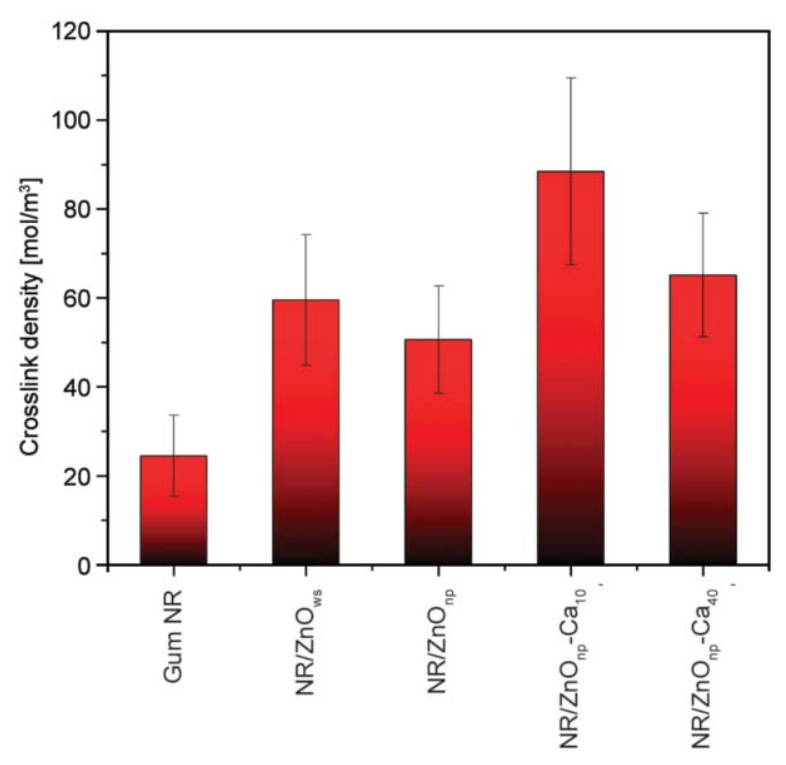

Figure 6. Crosslink density of $\mathrm{NR}$ films filled with $\mathrm{ZnO}_{\mathrm{ws}}$, $\mathrm{ZnO}_{\mathrm{np}}, \mathrm{ZnO}_{\mathrm{np}}-\mathrm{Ca}_{10}$ and $\mathrm{ZnO}_{\mathrm{np}}-\mathrm{Ca}_{40}$. relates to the activation of $\mathrm{ZnO}$ to the vulcanization propagation of the NR molecules. Although, $\mathrm{ZnO}_{\mathrm{np}}$ shows poor crosslinking capability due to the strong agglomeration of $\mathrm{ZnO}$. Its modification with $\mathrm{CaCO}_{3}$ provided significant improvement in the molecular chain crosslinks, as seen in NR vulcanizates filled with $\mathrm{ZnO}_{\mathrm{np}}-\mathrm{Ca}_{10}$ and $\mathrm{ZnO}_{\mathrm{np}}-\mathrm{Ca}_{40}$. The occurrence of chemical crosslinking of NR molecular chains through sulfur vulcanization system can be explained from the proposed model as shown in Figure 7. During the processes of curing at $70^{\circ} \mathrm{C}, \mathrm{ZnO}$ particles generate vulcanization [40]. Here, the $\mathrm{Zn}^{++}$forms a complex molecular structure with the ZDEC molecules in order to activate sulfur for beginning crosslinking propagation from the $S_{x}$ and $S_{y}$ radicals [40], as shown in Reaction (A) of Figure 7. Then, the breakages of sulfur radicals react individually with the NR molecular chains, performing chemical crosslinking of mono-, di- and polysulphidic linkages, as shown in the proposed Reaction (B) of Figure 7. This means that the degree of crosslinking of NR molecular chain depends on the amount of $\mathrm{Zn}^{++}$release from $\mathrm{ZnO}$ particles. For different types of $\mathrm{ZnO}$
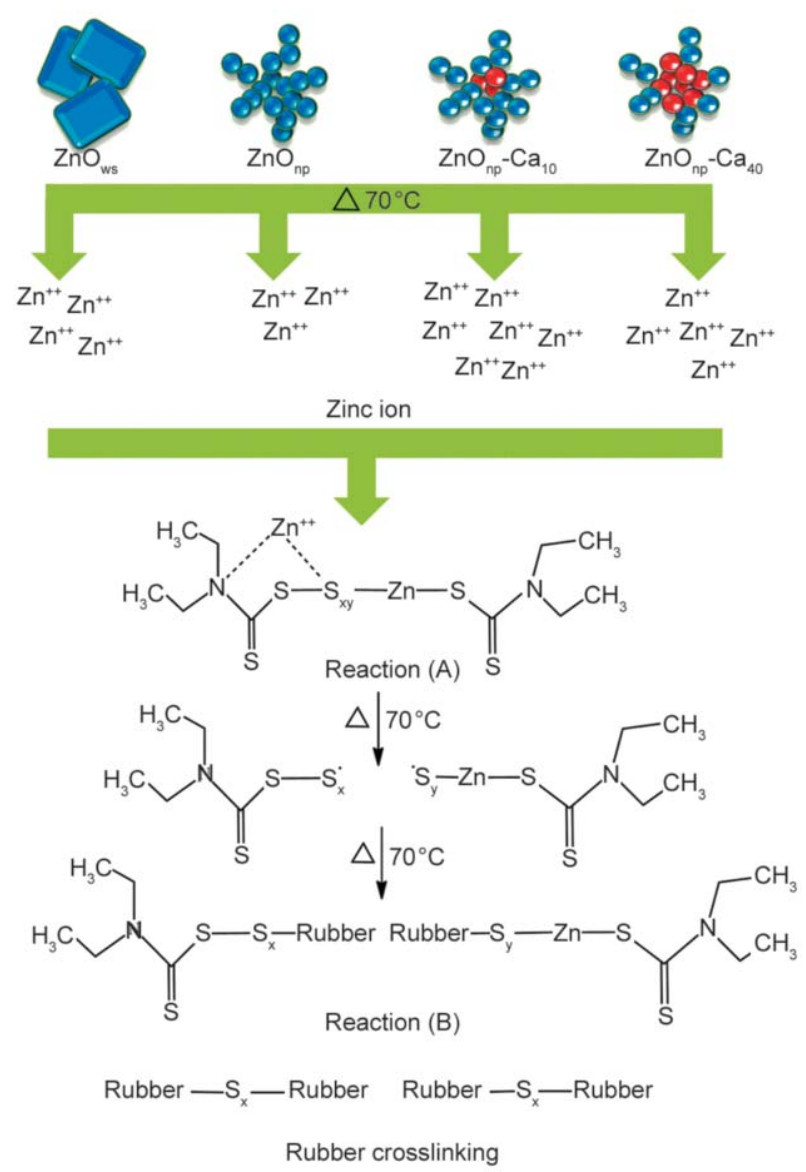

Figure 7. Proposed vulcanization model of NR films filled with $\mathrm{ZnO}_{\text {ws }}, \mathrm{ZnO}_{\mathrm{np}}, \mathrm{ZnO}_{\mathrm{np}}-\mathrm{Ca}_{10}$ and $\mathrm{ZnO}_{\mathrm{np}}-\mathrm{Ca}_{40}$. 
in the present work, the formation of chemical crosslinking is mainly due to two reasons: (i) $\mathrm{ZnO}$ dispersion and (ii) purity of $\mathrm{ZnO}$ (Table 1). Considering Figure 7 to explain the effect of $\mathrm{ZnO}$ dispersion, it is found that the highest amount of $\mathrm{Zn}^{++}$releases in the case of the NR films filled with $\mathrm{ZnO}_{\mathrm{np}}-\mathrm{Ca}_{10}$ and $\mathrm{ZnO}_{\mathrm{np}}-\mathrm{Ca}_{40}$. The lowest amount of such ions is formed in the composite with $\mathrm{ZnO}$ and $\mathrm{ZnO}_{\mathrm{np}}$. It can be related to their degree of dispersion, which causes different specific surface areas $[31,40]$. Therefore, poor crosslinking density is observed in the composite of uncoated $\mathrm{ZnO}$ particles. However, due to the less purity of $\mathrm{ZnO}_{\mathrm{np}}$ in the film with $\mathrm{ZnO}_{\mathrm{np}}-\mathrm{Ca}_{40}$, the highest crosslink density is observed in $\mathrm{NR} / \mathrm{ZnO}_{\mathrm{np}}-$ $\mathrm{Ca}_{10}$ film. In addition, the dispersion can be clearly confirmed from the morphologies of vulcanizates using SEM-EDX analyses, as shown in Figure 8. It is observed that the high level of agglomeration of $\mathrm{ZnO}$ occurs in the vulcanizate with $\mathrm{ZnO}_{\mathrm{np}}$ (Figures $8 \mathrm{~d}-8 \mathrm{f}$ ), whereas the one with both modified
$\mathrm{ZnO}_{\mathrm{np}}$ showed homogenous dispersion of the $\mathrm{ZnO}$ particles and $\mathrm{Zn}^{++}$. It is noted that the NR films with $\mathrm{ZnO}_{\mathrm{np}}-\mathrm{Ca}_{10}$ indicated better dispersion of $\mathrm{ZnO}$ throughout the NR matrix (Figures $8 \mathrm{~g}-8 \mathrm{i}$ )) and it shows the highest crosslink density of the vulcanizate. Strong agglomeration of $\mathrm{ZnO}_{\mathrm{np}}$ is also observed in the OM images, as shown in Figure 9. A smooth surface on the NR film is observed after the addition of $\mathrm{ZnO}, \mathrm{ZnO}_{\mathrm{np}}-\mathrm{Ca}_{10}$, and $\mathrm{ZnO}_{\mathrm{np}}-\mathrm{Ca}_{40}$, while a roughened surface is observed in the film with $\mathrm{ZnO}_{\text {np. }}$. Also, the agglomeration of $\mathrm{ZnO}_{\mathrm{np}}$ makes the composites stronger when the $\mathrm{ZnO}$ loading is increased from 3 to $7 \mathrm{phr}$. This is the result of decreased tensile strength of the NR film on increasing the amount of $\mathrm{ZnO}$ in the NR matrix. Concerning the purity of $\mathrm{ZnO}$ present in each composite as displayed in Table $1, \mathrm{ZnO}_{\mathrm{ws}}$ and $\mathrm{ZnO}_{\mathrm{np}}$ are highly purified, and the lowest one is found to be $\mathrm{ZnO}_{\mathrm{np}}-\mathrm{Ca}_{40}$. Theoretically, $\mathrm{ZnO}_{\mathrm{ws}}$ and $\mathrm{ZnO}_{\mathrm{np}}$ are expected to generate the highest $\mathrm{Zn}^{++}$and lead to exhibit the highest crosslink

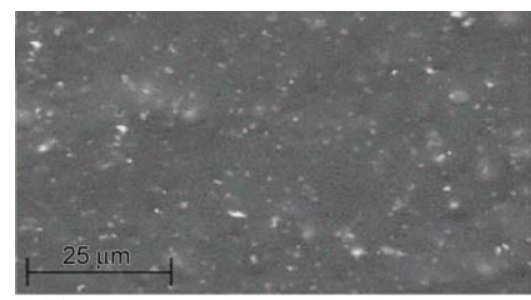

a)

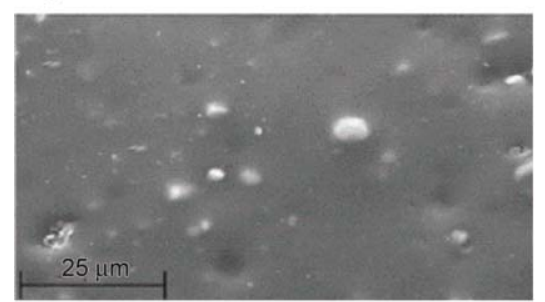

d)

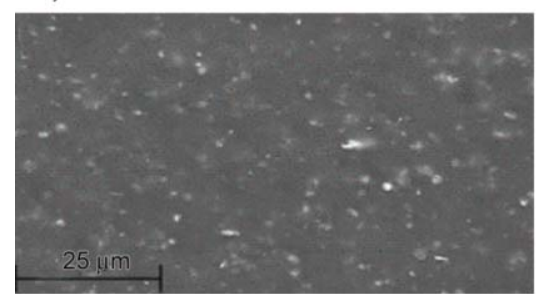

g)

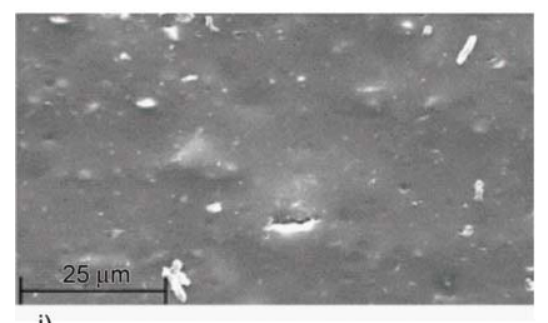

j)

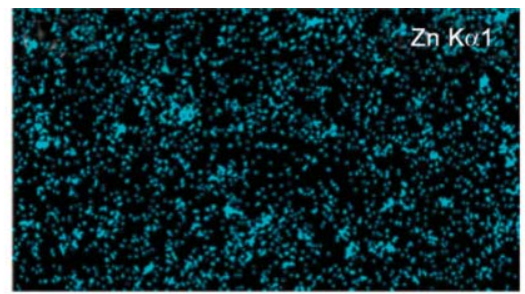

b)

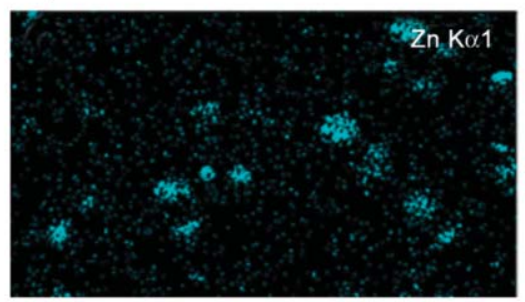

e)

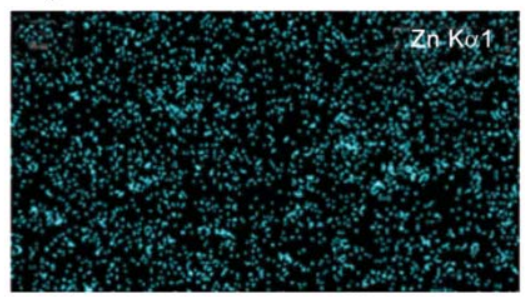

h)

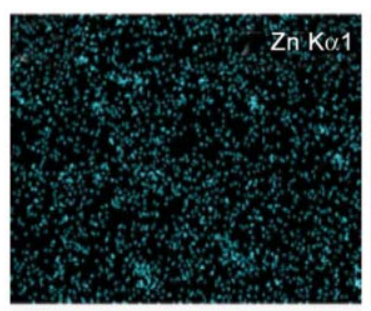

k)

l)

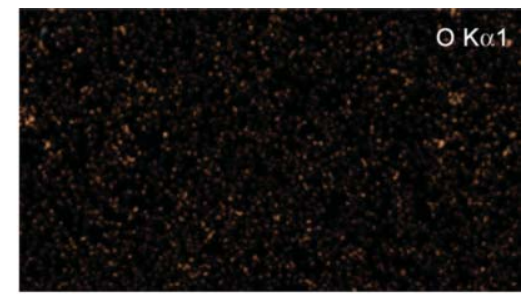

c)

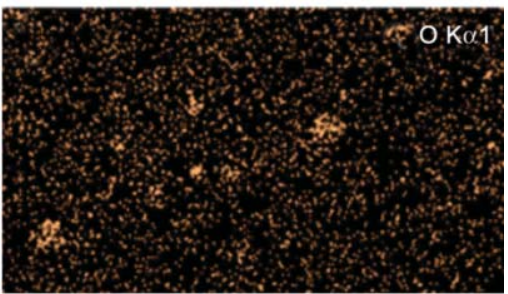

f)

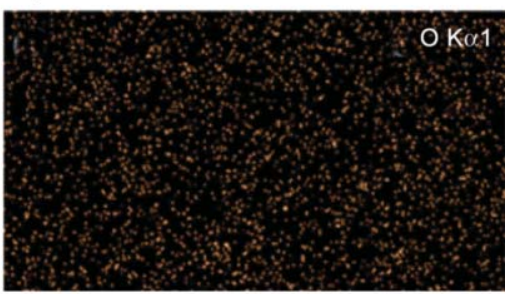

i)

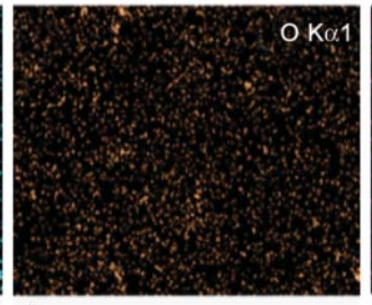

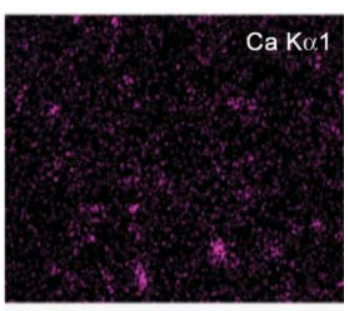

m)

Figure 8. SEM micrographs and its EDX mapping of $\mathrm{NR}$ films filled with $\mathrm{ZnO}_{\mathrm{ws}}(\mathrm{a}-\mathrm{c}), \mathrm{ZnO}_{\mathrm{np}}(\mathrm{d}-\mathrm{f}), \mathrm{ZnO}_{\mathrm{np}}-\mathrm{Ca}_{10}(\mathrm{~g}-\mathrm{i})$ and $\mathrm{ZnO}_{n p}-\mathrm{Ca}_{40}(\mathrm{j}-\mathrm{m})$. 


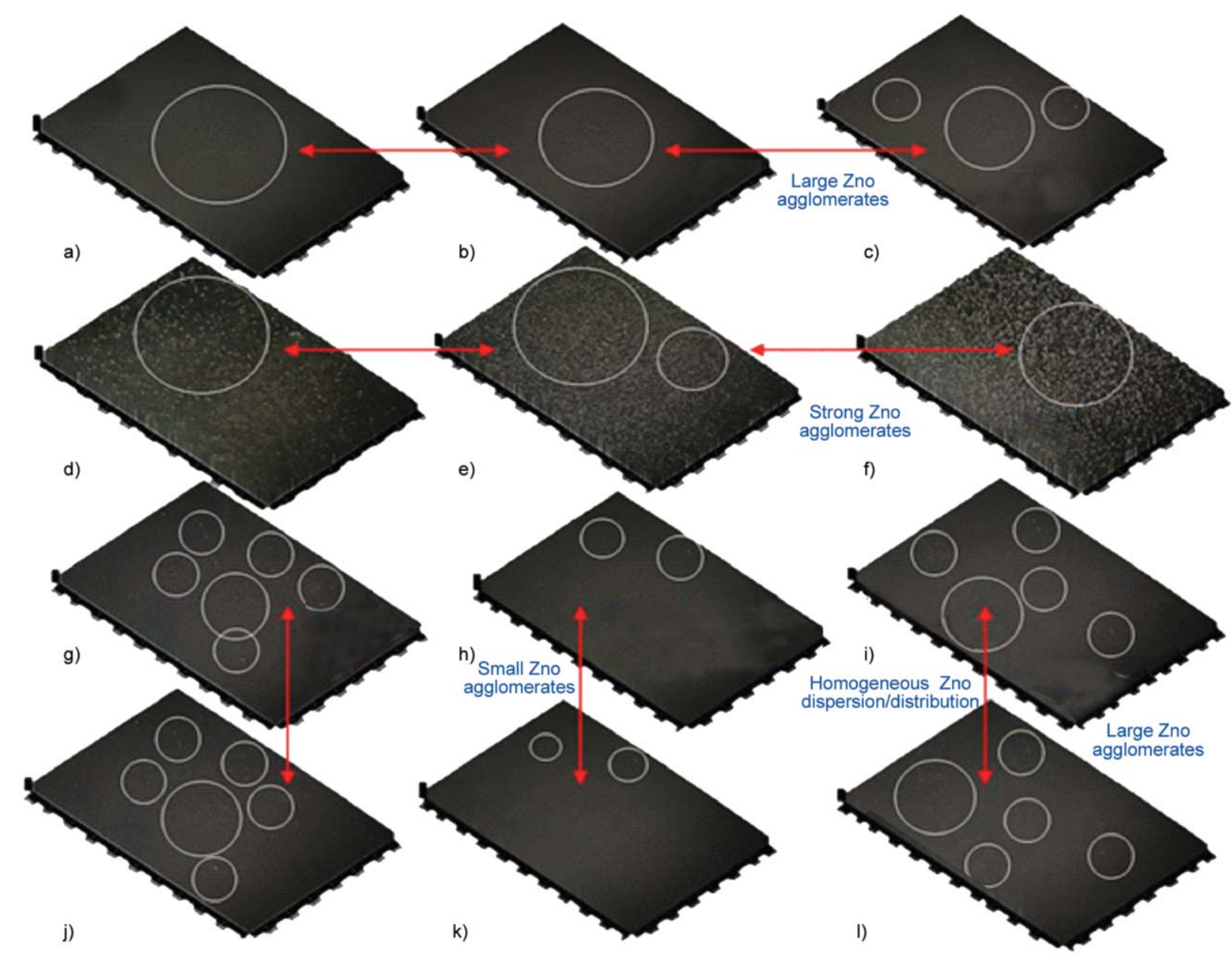

Figure 9. Light microscope images of $\mathrm{NR}$ films filled with $\mathrm{ZnO}_{\mathrm{ws}}(\mathrm{a}-\mathrm{c}), \mathrm{ZnO}_{\mathrm{np}}(\mathrm{d}-\mathrm{f}), \mathrm{ZnO}_{\mathrm{np}}-\mathrm{Ca}_{10}(\mathrm{~g}-\mathrm{i})$ and $\mathrm{ZnO}_{\mathrm{np}}-\mathrm{Ca}_{40}(\mathrm{j}-\mathrm{l})$ with concentrations 3,5 and $7 \mathrm{phr}$, respectively.

density than the other vulcanizates. However, higher level of agglomeration and larger particle sizes of the $\mathrm{ZnO}_{\mathrm{ws}}$, the vulcanizates filled with $\mathrm{ZnO}_{\mathrm{np}}-\mathrm{Ca}_{10}$ and $\mathrm{ZnO}_{\mathrm{np}}-\mathrm{Ca}_{40}$ have reached the optimum crosslinking ability of NR matrix and provided the highest tensile properties with homogenous dispersion of $\mathrm{ZnO}_{\mathrm{np}}$ throughout the NR matrix. This is a useful finding beneficial to NR industries to minimize the amount of $\mathrm{ZnO}$ in the NR matrix with better mechanical properties and crosslink density.

\subsection{Relation between thermal stability and thermo-mechanical relaxation}

In order to measure the thermal stability of the vulcanizates filled with different types of $\mathrm{ZnO}$ and $\mathrm{ZnO}_{\text {np }}$, TGA thermograms and their specific details by means of the decomposition temperature $\left(T_{\mathrm{d}}\right)$ and \%residual are presented in Figure 10 and Table 4. TGA thermograms reveal that the thermal decomposition under nitrogen $\left(\mathrm{N}_{2}\right)$ atmosphere of NR vulcanizates with and without $\mathrm{ZnO}_{\mathrm{ws}}$ and $\mathrm{ZnO}_{\mathrm{np}}$ is found at approximately $370{ }^{\circ} \mathrm{C}$, corresponding to the decomposition of the NR matrix. However, considering the decomposition temperature range of 350 $400^{\circ} \mathrm{C}$ in the inserted image (i) of Figure 10, a slight difference of $1.0-1.5^{\circ} \mathrm{C}$ in the $T_{\mathrm{d}}$ value is observed upon using $\mathrm{ZnO}_{\mathrm{ws}}$ and unmodified $\mathrm{ZnO}_{\mathrm{np}}$ although they have prepared by different procedures. Here, the $\mathrm{ZnO}_{\mathrm{ws}}$ is produced by French process based on combustion of zinc at $1230-1270^{\circ} \mathrm{C}$ [41], while $\mathrm{ZnO}_{\mathrm{np}}$ and its modification have been done based on a wet chemical process with spontaneous reaction at $154^{\circ} \mathrm{C}$ [34]. This $\mathrm{ZnO}_{\mathrm{np}}$ normally has poor thermal resistance than the one with the French process [41]. However, upon modification with $\mathrm{CaCO}_{3}$, the $T_{\mathrm{d}}$ of the film has no significant differences from the one with $\mathrm{ZnO}_{\text {ws }}$. This might be due to the improved dispersion of the $\mathrm{ZnO}_{\text {np }}$ particles throughout the rubber matrix. Negligible thermal stability of the NR film with $\mathrm{ZnO}_{\mathrm{ws}}$ is due to the benefit of combustion process can also be elucidated through the \%residual composition as shown in the inserted image (ii) of Figure 10. Here, the white residue of the film with $\mathrm{ZnO}_{\mathrm{ws}}$ is the remaining $\mathrm{ZnO}_{\mathrm{ws}}$ powder. A lower 


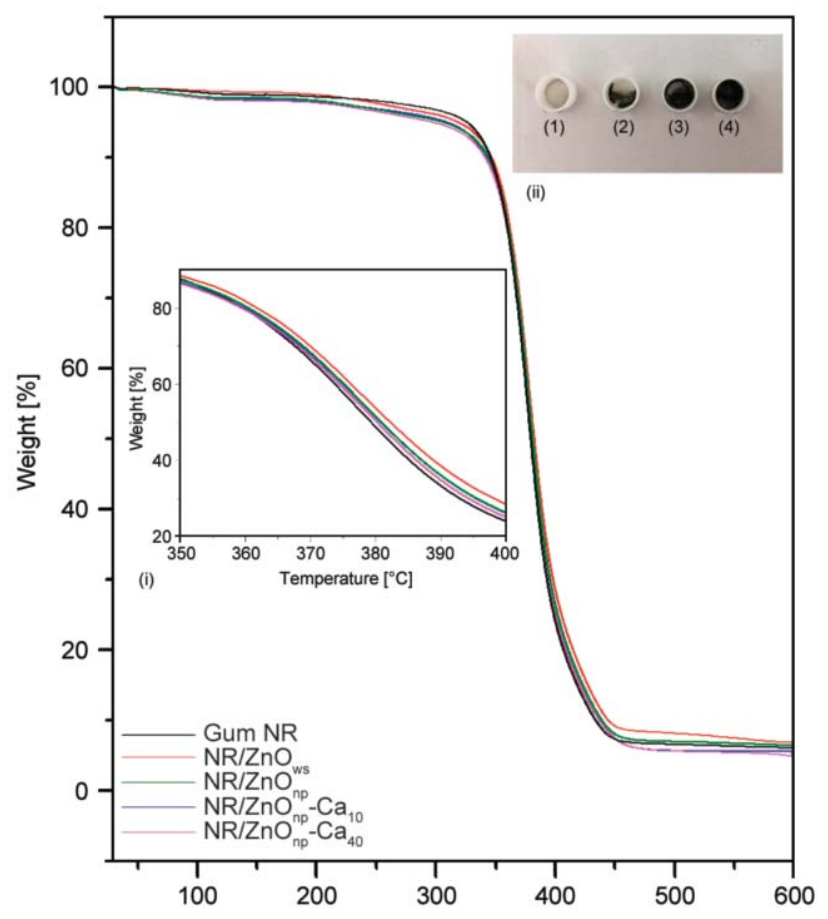

a)

Temperature $\left[{ }^{\circ} \mathrm{C}\right]$

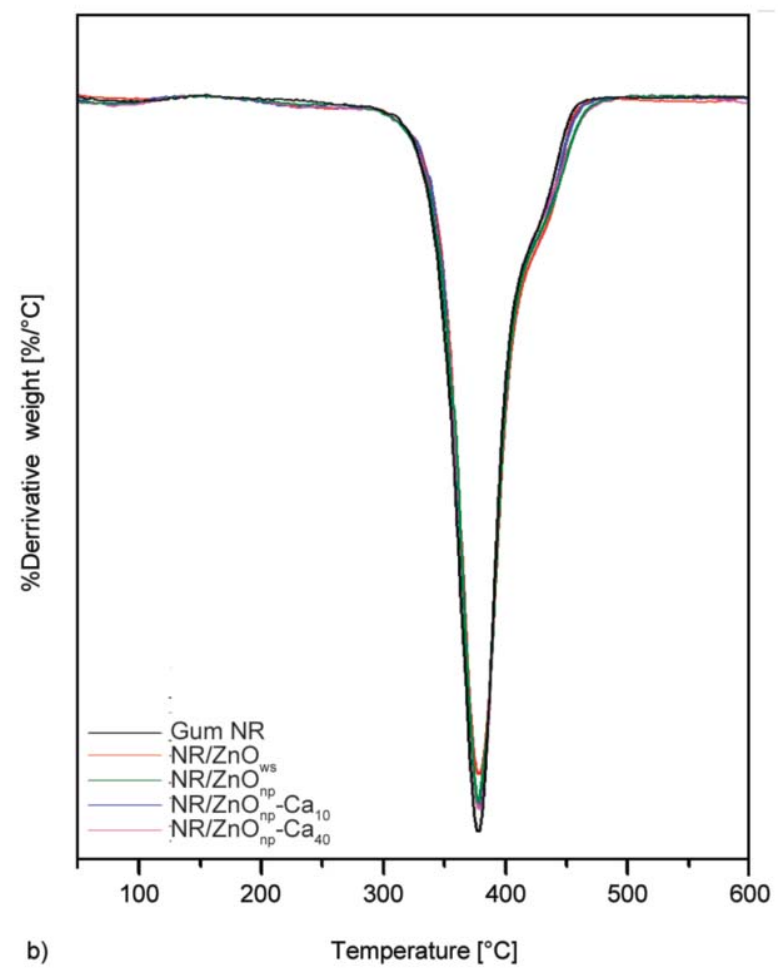

b)

Figure 10. TGA (a) and DTG (b) thermograms of $\mathrm{NR}$ films filled with $\mathrm{ZnO}_{\mathrm{ws}}, \mathrm{ZnO}_{\mathrm{np}}, \mathrm{ZnO}_{\mathrm{np}}-\mathrm{Ca}_{10}$ and $\mathrm{ZnO}_{\mathrm{np}}-\mathrm{Ca}_{40}$.

Table 4. Decomposition temperatures $\left(T_{\mathrm{d}}\right)$ and $\%$ residue of NR films filled with $\mathrm{ZnO}_{\mathrm{ws}}, \mathrm{ZnO}_{\mathrm{np}}, \mathrm{ZnO}_{\mathrm{np}}-\mathrm{Ca}_{10}$ and $\mathrm{ZnO}_{\mathrm{np}}-\mathrm{Ca}_{40}$.

\begin{tabular}{|l|c|c|}
\hline \multicolumn{1}{|c|}{ Samples } & $\begin{array}{c}\text { Decomposition temperature, } \boldsymbol{T}_{\mathbf{d}} \\
{\left[{ }^{\circ} \mathbf{C}\right]}\end{array}$ & \%Residue \\
\hline $\mathrm{Gum} \mathrm{NR}$ & 377.50 & 6.09 \\
\hline $\mathrm{NR} / \mathrm{ZnO}_{\mathrm{ws}}$ & 378.85 & 6.89 \\
\hline $\mathrm{NR} / \mathrm{ZnO}_{\mathrm{np}}$ & 377.50 & 6.39 \\
\hline $\mathrm{NR} / \mathrm{ZnO}_{\mathrm{np}}-\mathrm{Ca}_{10}$ & 378.50 & 5.53 \\
\hline $\mathrm{NR} / \mathrm{ZnO}_{\mathrm{np}}-\mathrm{Ca}_{40}$ & 378.33 & 4.87 \\
\hline
\end{tabular}

\%residual is observed after using ZnOnp and its modified forms due to those nano-particles have lower purity. It is noted that the different amount of residue in each film can be considered related to (i) the remaining $\mathrm{ZnO}$ or $\mathrm{ZnO}_{\mathrm{np}}$ and (ii) the carbon black based on decomposition of hydrocarbon NR molecules. Thus, due to the lower NR content and purity of $\mathrm{ZnO}_{\mathrm{np}}$ in cases of $\mathrm{ZnO}_{\mathrm{np}}-\mathrm{Ca}_{10}$ and $\mathrm{ZnO}_{\mathrm{np}}-$ $\mathrm{Ca}_{40}$, the residues of pure NR are higher than the composites films. This means that the NR films exhibited significant improvement in thermal stability together with lowering the non-environmental friendly components.

However, the thermal stability of the vulcanizates has been completely changed after measuring the thermo-mechanical stability using the recently developed technique TSSR. Here, the vulcanizates are stretched and recorded the stress relaxation on raising the temperature until it reaches the decomposition state. For the determination of stability, the temperatures at which the stress relaxation is reduced to 50 and $90 \%\left(T_{50}\right.$ and $\left.T_{90}\right)$ are explored [42]. Figure 11a shows the stress relaxation as a function of temperature for the NR vulcanizates filled with different types of $\mathrm{ZnO}_{\mathrm{ws}}$ and $\mathrm{ZnO}_{\mathrm{np}}$. Also, Table 5 summarizes the observed $T_{50}, T_{90}$, initial stress relaxation $(\sigma)$, and crosslink density of the samples. It is interestingly noted that the highest thermo-mechanical stability of the vulcanizates is found in the one filled with $\mathrm{ZnO}_{\mathrm{np}}-\mathrm{Ca}_{10}$, which replaces the $\mathrm{ZnO}_{\text {ws }}$ as displayed in the TGA. This means that the degradability of the vulcanizates has been changed after the extension of $50 \%$ strain. This is attributed to the SIC of the NR molecular chain which has initially formed as the crystallinity during extension of the samples based on the rearrangement of NR chains. Thus, $\mathrm{NR} / \mathrm{ZnO}_{\mathrm{np}}-$ $\mathrm{Ca}_{10}$ film, which contains homogenous dispersion of $\mathrm{ZnO}_{\text {np }}$ exhibits higher stability, showing $T_{50}$ and $T_{90}$ 1.36 and $4.08 \%$ higher than the other vulcanizates. On the other hand, as expected, the NR film filled with $\mathrm{ZnO}_{\mathrm{np}}$ showed the lowest thermo-mechanical stability compared to the other $\mathrm{ZnO}$-based vulcanizates due to the agglomeration of particles. Therefore, it summarizes that the NR vulcanizate filled with $\mathrm{ZnO}_{\mathrm{np}}-\mathrm{Ca}_{10}$ exhibited the highest capability to retard thermal degradation under an applied force. 

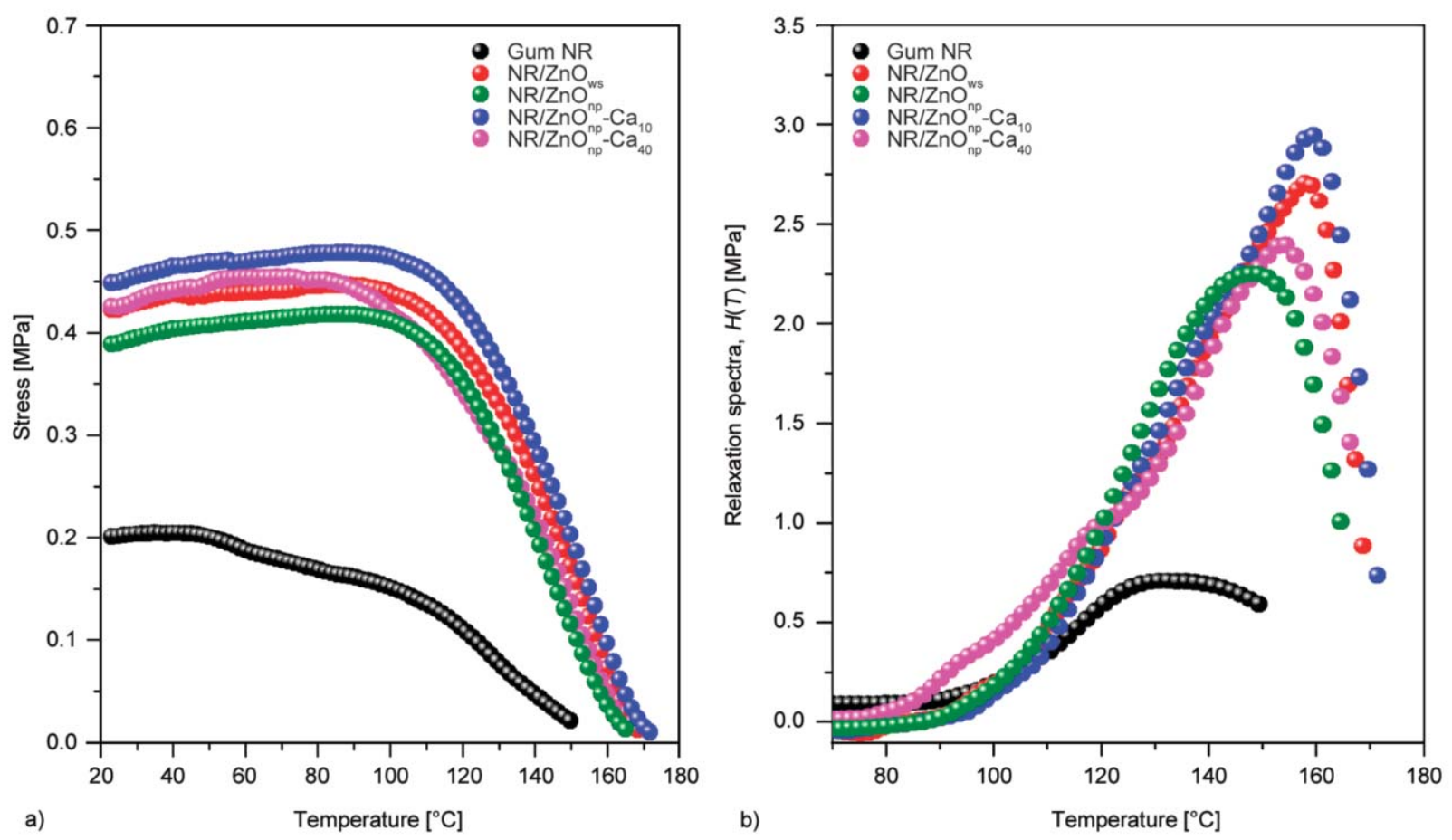

Figure 11. Stress relaxation (a) and relaxation spectra (b) of $\mathrm{NR}$ films filled with $\mathrm{ZnO}_{\mathrm{ws}}, \mathrm{ZnO}_{\mathrm{np}}, \mathrm{ZnO}_{\mathrm{np}}-\mathrm{Ca}_{10}$ and $\mathrm{ZnO}_{\mathrm{np}}-\mathrm{Ca}_{40}$.

TSSR not only indicates the thermal stability of the vulcanizates but also provides $\sigma$, which generally relates to the $50 \%$ modulus of the samples. The tensile strength values of the NR vulcanizates, as seen in Figure 3, are in good agreement with the $\sigma$ values. Vulcanizates filled with $\mathrm{ZnO}_{\mathrm{np}}-\mathrm{Ca}_{10}$ provided the highest $\sigma$ value, followed by the one with $\mathrm{ZnO}_{\mathrm{np}}-\mathrm{Ca}_{40}$, $\mathrm{ZnO}_{\mathrm{ws}}$, and $\mathrm{ZnO}_{\mathrm{np}}$. This is due to the homogeneous dispersion of modified $\mathrm{ZnO}_{\mathrm{np}}$ throughout the NR matrix, which effectively increases crosslinking propagation among the NR molecular chains and finally retards the breakages of the samples during extension. Figure 11a shows the stress relaxation is increased with increasing temperature approximately up to 50 $60^{\circ} \mathrm{C}$ related to the entropy effect of the NR molecular chain. This behavior can be used to estimate the crosslink density $(v)$ of the vulcanized samples through TSSR by Neo-Hookean equation (Equation (3)) [43]:

$\sigma=v \cdot R \cdot T\left(\frac{\lambda}{1+\alpha\left(T-T_{0}\right)}-\left(\frac{\lambda}{1+\alpha\left(T-T_{0}\right)}\right)^{2}\right)$

where $\lambda$ is the constant extension ratio, $\alpha$ is the thermal expansion coefficient $\left(2.43 \cdot 10^{-4} \mathrm{~K}^{-1}\right), R$ is the universal gas constant, and $\sigma$ is the stress at a reference temperature. Also, $T$ and $T_{0}$ are the reference-, and the initial temperatures of the measurements.

Table 5 depicts the crosslink density $v$ of the vulcanizates, and it shows the lowest value, approximately $62.06 \mathrm{~mol} / \mathrm{m}^{3}$, for the gum NR. An effective increase
Table 5. TSSR results in terms of $\sigma_{0}, T_{\mathrm{x}}$ and $v$ of NR films filled with $\mathrm{ZnO}_{\mathrm{ws}}, \mathrm{ZnO}_{\mathrm{np}}, \mathrm{ZnO}_{\mathrm{np}}-\mathrm{Ca}_{10}$ and $\mathrm{ZnO}_{\mathrm{np}}-$ $\mathrm{Ca}_{40}$.

\begin{tabular}{|l|c|c|c|c|}
\hline \multicolumn{1}{|c|}{ Samples } & $\begin{array}{c}\boldsymbol{\sigma}_{\mathbf{0}}{ }^{*} \\
{[\mathbf{M P a}]}\end{array}$ & $\begin{array}{c}\boldsymbol{T}_{\mathbf{5 0}}{ }^{\text {*** }} \\
{\left[{ }^{\circ} \mathbf{C}\right]}\end{array}$ & $\begin{array}{c}\boldsymbol{T}_{\mathbf{9}}{ }^{* * *} \\
\left.{ }^{\circ}{ }^{\circ} \mathbf{C}\right]\end{array}$ & $\begin{array}{c}\boldsymbol{v}^{*} \\
{\left[\mathbf{m o l} / \mathbf{m}^{\mathbf{3}}\right]}\end{array}$ \\
\hline $\mathrm{Gum} \mathrm{NR}$ & 0.20 & 123.50 & 150.20 & 62.06 \\
\hline $\mathrm{NR} / \mathrm{ZnO}_{\mathrm{ws}}$ & 0.42 & 145.70 & 163.20 & 147.37 \\
\hline $\mathrm{NR} / \mathrm{ZnO}_{\mathrm{np}}$ & 0.39 & 141.00 & 159.60 & 107.80 \\
\hline $\mathrm{NR} / \mathrm{ZnO}_{\mathrm{np}}-\mathrm{Ca}_{10}$ & 0.45 & 147.60 & 165.30 & 212.17 \\
\hline $\mathrm{NR} / \mathrm{ZnO}_{\mathrm{np}}-\mathrm{Ca}_{40}$ & 0.43 & 141.20 & 160.50 & 110.74 \\
\hline
\end{tabular}

${ }^{*} \sigma_{0}$ and $v$ are the initial stress at starting temperature and crosslink density.

${ }^{* *} T_{50}$ and $T_{90}$ are the temperature at which the forces were decreased to 50 and $90 \%$ from $\sigma_{0}$.

in $v$ of NR can be seen by the addition of $\mathrm{ZnO}_{\mathrm{ws}}$. However, this value is found to be lowered upon the incorporation of $\mathrm{ZnO}_{\mathrm{np}}$ due to its poor dispersion. By reducing the interaction among $\mathrm{ZnO}_{\mathrm{np}}$ by absorbing $\mathrm{CaCO}_{3}$, the crosslink density is significantly increased in the case of $\mathrm{NR} / \mathrm{ZnO}_{\mathrm{np}}-\mathrm{Ca}_{40}$ and NR/ $\mathrm{ZnO}_{\mathrm{np}}-\mathrm{Ca}_{10}$ vulcanizates. A considerable increment in the $\mathrm{v}$ value is achieved for the $\mathrm{NR} / \mathrm{ZnO}_{\mathrm{np}}-\mathrm{Ca}_{10}$ and correlated the results very well with the values indicated in Mooney-Rivlin and Flory-Rehner evaluations (Table 3). It clearly clarifies that the crosslink density of the vulcanizates has strongly related to $\mathrm{ZnO}_{\mathrm{ws}}$ and $\mathrm{ZnO}_{\mathrm{np}}$ dispersion, and therefore the one with $\mathrm{ZnO}_{\mathrm{np}}-\mathrm{Ca}_{10}$ showed the highest value even it consists of $\mathrm{ZnO}$, approximately $10 \%$ lower than the $\mathrm{ZnO}_{\text {ws. }}$. 
In addition, the thermo-mechanical degradation of stress relaxation temperature curves in Figure 11a shows a strong decomposition beyond $120^{\circ} \mathrm{C}$. This can be explained by the decomposition of polysulfidic bonding among NR molecular chain which is evaluated by differentiating the non-isothermal relaxation modulus $(E(T))$ at a constant heating rate $(v=$ $2{ }^{\circ} \mathrm{C} / \mathrm{min}$ ) using the Equation (4). This calculation provides the equation for relaxation spectrum $(H(T))$ as a function of temperature:

$$
H(T)=-T\left[\frac{\mathrm{d} E(T)}{\mathrm{d} T}\right]_{v=\text { const }}
$$

Figure $11 \mathrm{~b}$ shows relaxation spectra of gum NR, $\mathrm{ZnO}_{\mathrm{ws}}, \mathrm{ZnO}_{\mathrm{np}}-\mathrm{Ca}_{10}$, and $\mathrm{ZnO}_{\mathrm{np}}-\mathrm{Ca}_{40}$-filled NR films. Relevant peaks are indicated in the temperature range of $100-180^{\circ} \mathrm{C}$, which is directly assigned to the decomposition of $-\mathrm{C}-\mathrm{S}_{\mathrm{x}}-\mathrm{C}-$ chemical crosslinks in the NR matrix [44] designated as peak $\beta$. Therefore, the height of the peak can be interpreted as the existing conventional crosslinking density of the samples. In Figure $11 \mathrm{~b}$, it is seen that gum NR showed the lowest intensity of peak $\beta$, which means the lowest $-\mathrm{C}-\mathrm{S}_{\mathrm{x}}-\mathrm{C}-$ bonding, resulting in low $\sigma$ and mechanical properties together with poor $T_{50}$ and $T_{90}$. For the same reason, the incorporation of $\mathrm{ZnO}_{\mathrm{np}}$ resulted in the low peak height compared to the other NR vulcanizates filled with different $\mathrm{ZnO}_{\mathrm{ws}}$ and $\mathrm{ZnO}_{\mathrm{np}}$ due to the poor dispersion of $\mathrm{ZnO}_{\mathrm{np}}$ throughout the NR matrix. On the other hand, the addition of $\mathrm{ZnO}_{\mathrm{np}}-\mathrm{Ca}_{10}$ effectively increases the peak intensity. This means that the vulcanizate has optimal crosslink degrees due to the generation of $-\mathrm{C}-\mathrm{S}_{\mathrm{x}}-\mathrm{C}-$ chemical bonds. As expected, this correlates to the state of $\mathrm{ZnO}_{\mathrm{np}}$ dispersion which can act as the activator for NR molecules developed bonding among allylic carbon atoms within the NR molecular chains. It is also seen that the incorporation of $\mathrm{ZnO}_{n p}-\mathrm{Ca}_{40}$ has also exhibited higher peak intensity than the one with $\mathrm{ZnO}_{\mathrm{np}}$ even it consists of approximately $60 \% \mathrm{ZnO}_{\mathrm{np}}$. Therefore, all the results are well correlated with the properties observed for the NR films related to mechanical properties (Figure 3), initial stress relaxation (Figure 11) and the crosslink density via Mooney-Rivlin plot (Figure 5), swellability (Figure 6) and TSSR (Figure 11).

\subsection{Antibacterial properties}

The incorporation of modified- $\mathrm{ZnO}_{\mathrm{np}}$ has been strongly affected the properties of NR films in terms of their mechanical, dynamical, and thermal stability based on the nature of dispersion of $\mathrm{ZnO}$ particles. However, $\mathrm{ZnO}$ has also exhibited good performance due to its excellent anti-microbial properties. To study the benefit of using NR films, NR vulcanizates filled with $\mathrm{ZnO}_{\mathrm{ws}}, \mathrm{ZnO}_{\mathrm{np}}$, and modified $\mathrm{ZnO}_{\mathrm{np}}$ are introduced to evaluate their disinfection ability by means of qualitative and quantitative determination against Gram-negative E. coli which has been reported as the most common type of bacteria causing infection [45], including cholecystitis, bacteremia, cholangitis, urinary tract infection (UTI), traveler's diarrhea and also other clinical infections such as neonatal meningitis and pneumonia $[46,47]$. As a result, the qualitative clearing zone or inhibition zone after the bacterial infection is examined, as seen in Figure 12. It is observed that the controlled NR film, which is an $\mathrm{NR}$ vulcanizate without $\mathrm{ZnO}$ showed no clear zone. It clearly indicates that the gum NR has no ability to suppress the $E$. coli bacteria. In contrast, the clearing zone can be clearly observed after the addition of $\mathrm{ZnO}$ into the NR matrix. This indicates the antibacterial performance of the films by creating the reactive oxygen species (ROS) and solubilized zinc (II) ion $\left(\mathrm{Zn}^{++}\right)$to destroy the bacteria's cell wall [48], as

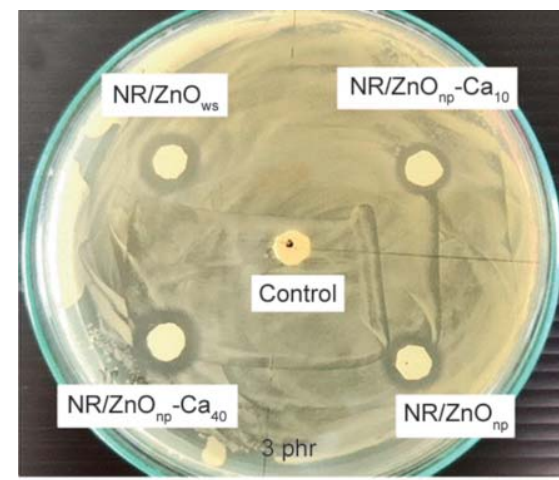

a)

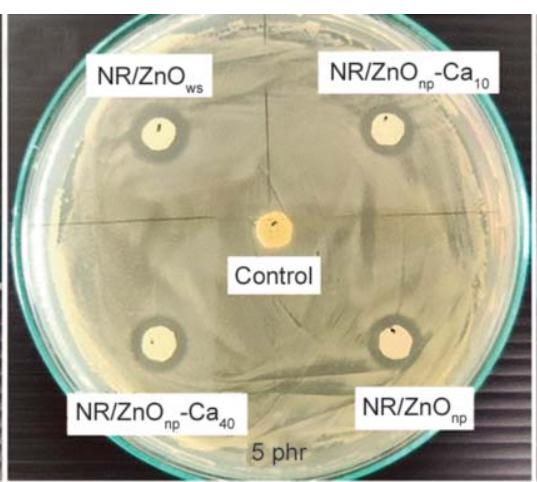

b)

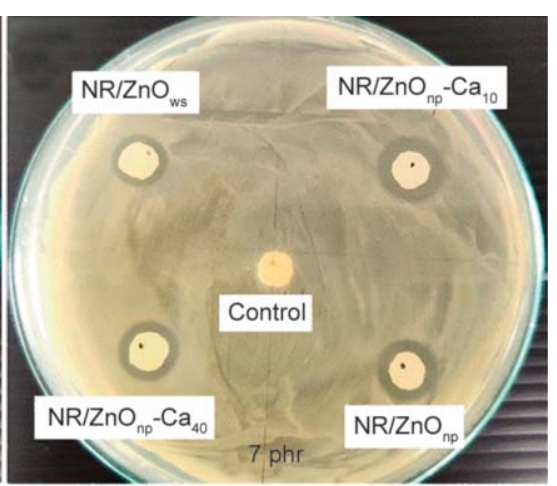

c)

Figure 12. The qualitative anti-microbial activities against Gram-negative E. coli of NR films filled with $\mathrm{ZnO}_{\mathrm{ws}}, \mathrm{ZnO}_{\mathrm{np}}$, $\mathrm{ZnO}_{\mathrm{np}}-\mathrm{Ca}_{10}$ and $\mathrm{ZnO}_{\mathrm{np}}-\mathrm{Ca}_{40}$ at the loading of 3 (a), 5 (b) and $7 \mathrm{phr}$ (c). 


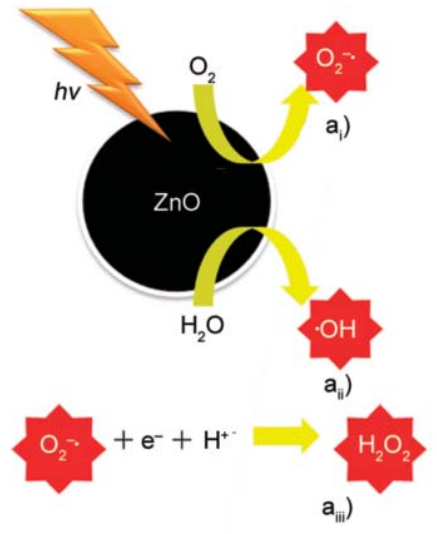

a)

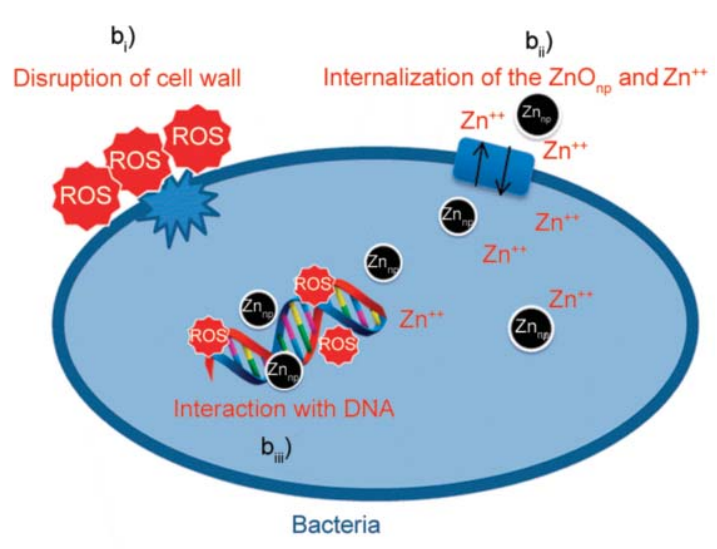

b)

Figure 13. Proposed model of anti-microbial mechanism of NR films filled with $\mathrm{ZnO}$. a) Photocatalytic process of $\mathrm{ZnO}$ with light and moisture and $\mathrm{b}$ ) attacking of ROS and $\mathrm{Zn}$ ions to the bacteria.

shown in the proposed model (Figure 13). Although the disinfection mechanism of pure $\mathrm{ZnO}_{\mathrm{np}}$ has not been proven yet and several proposed models have been provided by researchers from various fields. However, based on the interpretation mechanism of $\mathrm{ZnO}_{\mathrm{np}}$-filled NR vulcanizates, there is no prior clarity in the explanation. Figure 13a shows the first proposed mechanism originated from the physical and chemical interactions of the $\mathrm{ZnO}$ or $\mathrm{ZnO}_{\mathrm{np}}$ surfaces with light and moisture. This causes ROS absorption on $\mathrm{ZnO}_{\mathrm{np}}$ surfaces by means of superoxide anion $\left({ }^{\circ} \mathrm{O}_{2}^{-}\right)$(Figure $13 \mathrm{a}_{\mathrm{i}}$ ) and hydroxyl radicals $\left({ }^{\circ} \mathrm{OH}\right)+$ proton $\left(\mathrm{H}^{+}\right)$(Figure 13a $\mathrm{a}_{\mathrm{ii}}$ ). These are originated from the reaction of positive holes $\left(\mathrm{h}^{+}\right)$in the valence band (VB) and free electrons $\left(\mathrm{e}^{-}\right)$in the conduction band (CV) of the $\mathrm{ZnO}_{\mathrm{np}}$ to the moisture molecules $\left(\mathrm{H}_{2} \mathrm{O}\right)$ and oxygen gas $\left(\mathrm{O}_{2}\right)$, respectively [49-51]. It is noted that the ${ }^{\circ} \mathrm{O}_{2}{ }^{-}$is further reacted with $\mathrm{H}^{+}$and forms $\cdot \mathrm{HO}_{2}$. Later on, this product is found to be interacted with $\mathrm{H}^{+}$and $\mathrm{e}^{-}$before generating the hydrogen peroxide $\left(\mathrm{H}_{2} \mathrm{O}_{2}\right)$, as shown in (Figure $\left.13 \mathrm{a}_{\mathrm{iii}}\right)$. This means that the $\mathrm{ZnO}_{\mathrm{np}}$ surface consists of ${ }^{\bullet} \mathrm{O}_{2}^{-},{ }^{\bullet} \mathrm{OH}$ and $\mathrm{H}_{2} \mathrm{O}_{2}$. However, the negative charges of ${ }^{\circ} \mathrm{O}_{2}{ }^{-}$and ${ }^{\circ} \mathrm{OH}$ cannot penetrate into the negative charges of bacteria membrane, and the $\mathrm{H}_{2} \mathrm{O}_{2}$ molecules have the access and make injuries. Finally, it destroys the cells and triggers cell death due to the destruction of cellular components such as lipid, protein, and DNA (Figure $13 b_{i}$ ). This phenomenon leads to the dysfunctionality of membrane and cell wall of bacteria, resulting in oxidative stress towards the bacteria relating internalization of the $\mathrm{ZnO}_{\mathrm{np}}$ particles into the cell and further the microbe cannot be survived. However, during internalization into the cytoplasmic area of bacteria, it has not only from the $\mathrm{ZnO}_{\mathrm{np}}$, but also from the solubilized $\mathrm{Zn}^{++}$present in the rubber matrix as well as the dissolution of $\mathrm{ZnO}_{\mathrm{np}}$ with the medium including bacteria (particularly the cytoplasm which consists of $80 \%$ water) [52-55], as shown in Figure $13 b_{\mathrm{ii}}$. With the electrostatic interaction of the $\mathrm{Zn}^{++}$and $\mathrm{ZnO}_{\mathrm{np}}$, disruption of DNA replication on the cellular of bacteria occurs due to the effect of active transport inhibition along with the amino acid metabolism and the disturbance of the enzyme system $[56,57]$, as observed in Figure $13 b_{\text {iii. }}$.

According to the mechanism summarized in the proposed model (Figure 13), attacking of ROS and $\mathrm{Zn}^{++}$ to the bacteria is strongly dependent on the active surface area of $\mathrm{ZnO}$ in order to increase the ability to generate active species on $\mathrm{ZnO}$ surfaces and also to enhance the penetration ability of $\mathrm{ZnO}$ particles and $\mathrm{Zn}^{++}$into the cell. Therefore, the purity and particle size of $\mathrm{ZnO}$ during dispersion in the NR matrix need to be clarified. Comparing two different methods of adding $\mathrm{ZnO}$ into the NR matrix, as shown in Figure 14, indicated significant differences in the disinfection behavior. Figure 14a does not show the clear zone in NR films prepared directly by adding $5 \mathrm{phr}$ of $\mathrm{ZnO}$ into NR without dipping processes. On the other hand, Figure $14 \mathrm{~b}$ shows clear zones in the case of the samples prepared using the dipping procedure due to the killing of bacteria. This can be explained from the NR layers with different thickness covering on the $\mathrm{ZnO}$ particles (Figure 14c and 14d), which relates directly to the electrostatic transfer of $\mathrm{ZnO}$ particles and their active ion species. In addition, it has been reported that the photocatalytic activity of $\mathrm{ZnO}$ was reduced by incorporating into NR [58]. However, it has to be noted that the exact evaluation of the NR layer absorbed on the $\mathrm{ZnO}$ surfaces 

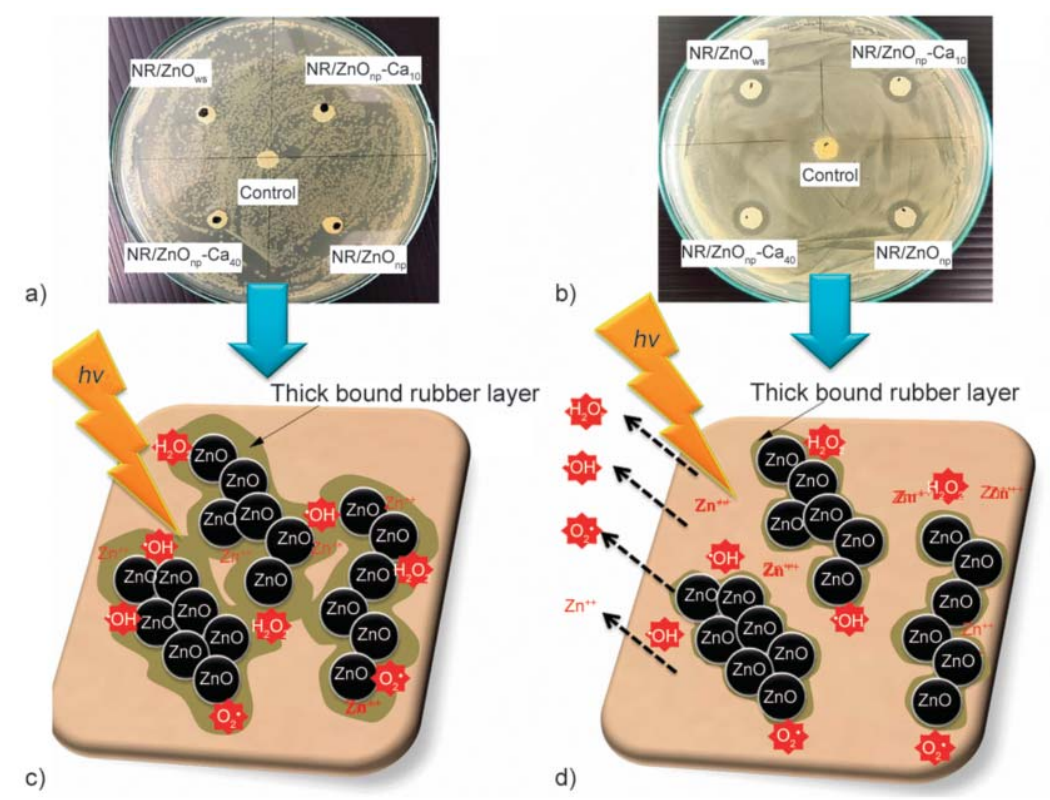

Figure 14. The clear zone of NR films prepared by directly adding 5 phr of $\mathrm{ZnO}$ in the cases of without (a) and with (b) dipping processes together with their proposed models (c) and (d).

cannot be clearly detected through bound rubber layer determination and morphologies since the $\mathrm{ZnO}$ concentration is too less relative to the NR matrix. Thus, the model is interpreted based on the different results of anti-microbe degrees. From Figures $14 \mathrm{c}$ and $14 \mathrm{~d}$, the generation of $\mathrm{e}^{-}$and $\mathrm{h}^{+}$has been occurred directly on the $\mathrm{ZnO}$ surfaces together with the solubilized $\mathrm{Zn}^{++}$as a result of the interaction with the accelerator component in the NR film during the curing process. Here, such active ions can move across the NR layer by the electrostatic force with a negative charge of bacteria surfaces when the layer has a thickness lower than $4 \mathrm{~nm}[4,59]$. Therefore, in the case of using the dipping process, the thickness of the NR layer has lowered when compared to the one with a direct mixing process. Here, the interaction leads to the generation of ROS components and the movement of $\mathrm{Zn}^{++}$into bacteria cellular have been well originated. This is the reason for providing a clear zone, as seen in Figures 12 and 14. However, this phenomenon has a strong relation with the degree of

Table 6. Diameters of the clear zone for NR films filled with different types of $\mathrm{ZnO}$ at various concentrations.

\begin{tabular}{|l|c|c|c|}
\hline \multirow{2}{*}{\multicolumn{1}{|c|}{ Samples }} & \multicolumn{3}{|c|}{$\begin{array}{c}\text { Diameter } \\
\text { [cm] }\end{array}$} \\
\cline { 2 - 4 } & $\mathbf{3 ~ p h r}$ & $\mathbf{5}$ phr & 7 phr \\
\hline $\mathrm{NR} / \mathrm{ZnO}_{\mathrm{ws}}$ & $1.00 \pm 0.10$ & $1.10 \pm 0.90$ & $1.00 \pm 0.85$ \\
\hline $\mathrm{NR} / \mathrm{ZnO}_{\mathrm{np}}$ & $0.90 \pm 0.09$ & $1.00 \pm 0.70$ & $1.15 \pm 0.10$ \\
\hline $\mathrm{NR} / \mathrm{ZnO}_{\mathrm{np}}-\mathrm{Ca}_{10}$ & $0.80 \pm 0.07$ & $1.00 \pm 0.80$ & $1.20 \pm 0.99$ \\
\hline $\mathrm{NR} / \mathrm{ZnO}_{\mathrm{np}}-\mathrm{Ca}_{40}$ & $1.20 \pm 0.08$ & $1.10 \pm 0.78$ & $1.10 \pm 0.80$ \\
\hline
\end{tabular}

dispersion of $\mathrm{ZnO}_{\mathrm{ws}}$ and $\mathrm{ZnO}_{\mathrm{np}}$ with and without modification. Agglomeration of $\mathrm{ZnO}$ might be the reason for lowering antibacterial activity of the films. Table 6 shows the observed diameters of the clear zone in case of each $\mathrm{ZnO}$ types at various concentrations. No significant differences are observed in the values except the films with $\mathrm{ZnO}_{\text {ws }}$ which has strong agglomeration of large $\mathrm{ZnO}$ particles. Interestingly, the indistinguishable qualitative results of the NR films filled with unmodified and modified $\mathrm{ZnO}_{\mathrm{np}}$ by varying their contents are represented. This relates to the high surface areas of the fine dispersion of $\mathrm{ZnO}_{\mathrm{np}}$ which is well active to generate ROS and $\mathrm{Zn}^{++}$for penetrating the bacterial cells.

Compared to the qualitative analysis, only $5 \mathrm{phr}$ of each $\mathrm{ZnO}$ type are selected for investigating the quantitative determination of bacterial activity. Characterization is performed by using the observed optical intensity of bacteria suspension based on E. coli (Gram-negative) received from the spectrophotometer at a wavelength of $600 \mathrm{~nm}\left(O D_{600}\right)$, and the results are as shown in Figure 15. Here, the $O D_{600}$ is reported for the Luria Broth medium of $E$. coli that incubated at temperature $37^{\circ} \mathrm{C}$ with each $\mathrm{ZnO}$-filled NR film of $1,2,4$, and $6 \mathrm{~h}$ using the initial bacteria suspension of $0.2\left(O D_{600}=0.2\right)$. It is revealed that the gum NR exhibited a considerable increase in $O D_{600}$ as a function of time, indicating the growth of $E$. coli under controlled conditions. This confirms that there is no antibacterial activity against $E$. coli, and it is well related to the none qualitative clear zone (Figure 12). It 


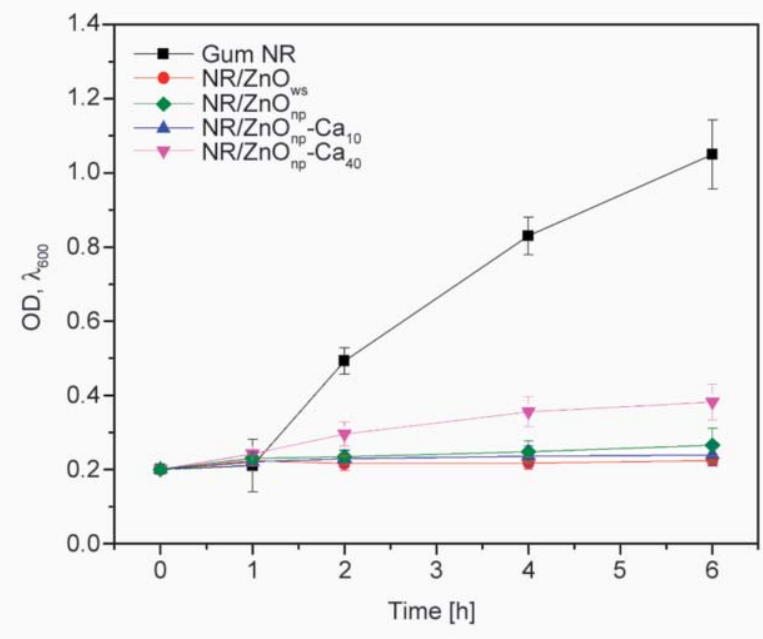

Figure 15. Optical density of bacteria suspension E. coli (Gram negative) by spectrophoto- metry at a wavelength of $600 \mathrm{~nm}$ for NR films filled with $\mathrm{ZnO}_{\mathrm{ws}}, \mathrm{ZnO}_{\mathrm{np}}, \mathrm{ZnO}_{\mathrm{np}}-\mathrm{Ca}_{10}$ and $\mathrm{ZnO}_{\mathrm{np}}-\mathrm{Ca}_{40}$.

is seen in Figure 14 that $O D_{600}$ decreases upon the addition of $60 \% \mathrm{ZnO}_{\mathrm{np}}$ to the $\mathrm{NR}$ film filled with $\mathrm{ZnO}_{\mathrm{np}}{ }^{-}$ $\mathrm{Ca}_{40}$. Liberation of $\mathrm{Zn}^{++}$and $\mathrm{H}_{2} \mathrm{O}_{2}$ occurs and reacts effectively with the microbe cell at the membrane and cytoplast regions. This is also the result of non-increasing of $O D_{600}$ on the incorporation of $\mathrm{ZnO}_{\mathrm{ws}}$, $\mathrm{ZnO}_{\mathrm{np}}$ and $\mathrm{ZnO}_{\mathrm{np}}-\mathrm{Ca}_{10}$. The results show no significant differences at $6 \mathrm{~h}$ of test; even they have different $\mathrm{ZnO}$ purity. This means that the addition of modified $\mathrm{ZnO}_{\mathrm{np}}$, especially $\mathrm{ZnO}_{\mathrm{np}}-\mathrm{Ca}_{10}$, exhibited better dispersion which causes a different degree of liberation of $\mathrm{Zn}^{++}$and $\mathrm{H}_{2} \mathrm{O}_{2}$ to attack the microorganism. It has the benefit of lowering the usage of $\mathrm{ZnO}$ in the NR film, which minimizes the non-environmental friendly material while the properties are significantly improved along with antibacterial performance.

The activity of bacteria can also be elucidated through the degree of inhibition by Equation (5):

$\%$ inhibition $(\omega)=\frac{N}{N_{0}} \cdot 100$

where $N_{0}$ and $N$ are the mean values of bacteria concentrations from $O D_{600}$ on the gum NR and its films with different $\mathrm{ZnO}$ types, respectively.

Figure 16 shows the \%inhibition of bacteria activity in NR film with and without $\mathrm{ZnO}$ for $6 \mathrm{~h}$. It is seen that the values of $\omega$ show as almost constant after incubating for $1 \mathrm{~h}$. However, the values are found to be drastically increased beyond the incubating period of 1 up to $2 \mathrm{~h}$, and slightly increases during 4-6 h for all the films using $\mathrm{ZnO}_{\mathrm{ws}}$ and $\mathrm{ZnO}_{\mathrm{np}}$ with and without modification. Here, the different types of

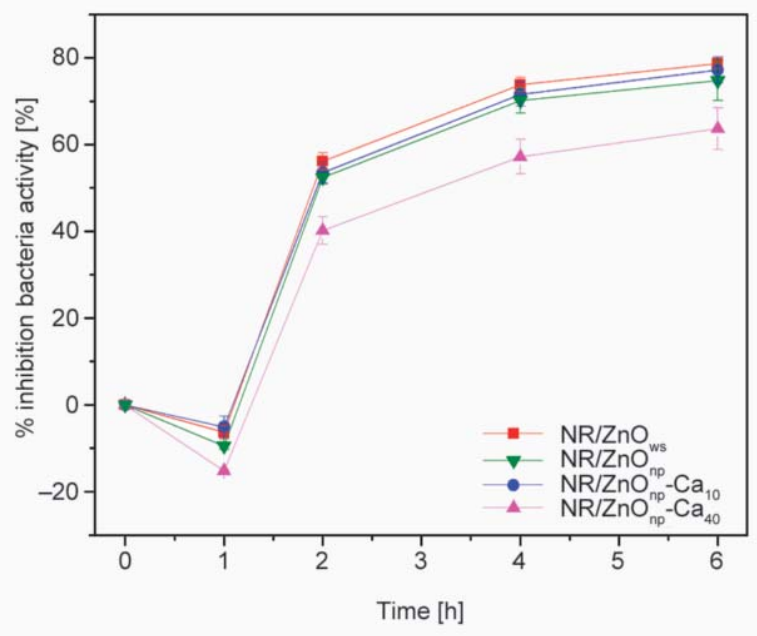

Figure 16. \% Inhibition bacteria activity of $\mathrm{NR}$ films filled with $\mathrm{ZnO}_{\mathrm{ws}}, \mathrm{ZnO}_{\mathrm{np}}, \mathrm{ZnO}_{\mathrm{np}}-\mathrm{Ca}_{10}$ and $\mathrm{ZnO}_{\mathrm{np}}-\mathrm{Ca}_{40}$.

$\mathrm{ZnO}$ provided distinct values of $\omega$. The NR film filled with $\mathrm{ZnO}_{\mathrm{np}}-\mathrm{Ca}_{40}$ showed a lower value than the films filled with $\mathrm{ZnO}_{\mathrm{ws}}, \mathrm{ZnO}_{\mathrm{np}}$, and $\mathrm{ZnO}_{\mathrm{np}}-\mathrm{Ca}_{10}$. This is mainly due to the different percentages of $\mathrm{ZnO}$ used in each film. As seen in Table $1, \mathrm{ZnO}_{\mathrm{np}}-$ $\mathrm{Ca}_{40}$ consists of the lowest $\mathrm{ZnO}$ purity of $60 \%$, whereas the $\mathrm{ZnO}_{\mathrm{ws}}, \mathrm{ZnO}_{\mathrm{np}}$, and $\mathrm{ZnO}_{\mathrm{np}}-\mathrm{Ca}_{10}$ composed the $\mathrm{ZnO}$ of approximately 99,97 , and $90 \%$, respectively. With a $10 \%$ difference in the $\mathrm{ZnO}$ content, the NR film filled with $\mathrm{ZnO}_{\mathrm{np}}-\mathrm{Ca}_{10}$ showed comparatively better results. This means that the particle size and the dispersion of $\mathrm{ZnO}$ are played the most important role in the anti-microbial activity of NR films. Modification of $\mathrm{ZnO}_{n p}$ with $\mathrm{CaCO}_{3}$ clearly exhibited an effective improvement in the properties of NR films compared to the $\mathrm{ZnO}_{\mathrm{np}}$, which forms strong agglomeration during mixing with NR in latex states. Although there are no significant differences in the anti-microbial ability of the resulting composite, mechanical (Figures 3 and 5) and thermo-mechanical properties (Figure 11 and Table 5) are clearly improved. It proves well the effect of film processing and modification of $\mathrm{ZnO}_{\mathrm{np}}$ for enhancing the properties effectively and upheaving the applications of $\mathrm{Nr}$ films in the near future products.

\section{Conclusions}

$\mathrm{NR}$ films filled with $\mathrm{ZnO}_{\mathrm{ws}}, \mathrm{ZnO}_{\mathrm{np}}, \mathrm{ZnO}_{\mathrm{np}}-\mathrm{Ca}_{10}$, and $\mathrm{ZnO}_{\mathrm{np}}-\mathrm{Ca}_{40}$ were prepared via latex mixing technique. To determine the effect of surface area and degree of dispersion of $\mathrm{ZnO}$, the mechanical properties, crosslink density, thermal stability, morphology, thermomechanical properties, and anti-microbial activity of films were studied. It was found that the nature of 
dispersion of $\mathrm{ZnO}$ plays an important role in the improvement of crosslink density and mechanical properties of the films. Both the properties were improved considerably after the modification of $\mathrm{ZnO}_{\mathrm{np}}$ surface with $\mathrm{CaCO}_{3}$. This lead to hinder Van-der Waals force of attraction among $\mathrm{ZnO}_{\mathrm{np}}$ particles, and the $\mathrm{ZnO}_{\mathrm{np}}$ effectively activated the crosslinking propagation. The presented results were in good agreement with the observed relevant properties based on Mooney-Rivlin plotting, film swelling, and TSSR measurements. On the other hand, significantly poor properties were observed for the unmodified- $\mathrm{ZnO}_{\text {np }}$ reinforced $\mathrm{NR}$ due to the strong $\mathrm{ZnO}_{\mathrm{np}}$ agglomeration. The anti-microbial activities in terms of qualitative and quantitative determination against Gram-negative E. coli, it was found that the incorporation of modified- $\mathrm{ZnO}_{\mathrm{np}}$, particularly $\mathrm{ZnO}_{\mathrm{np}}-\mathrm{Ca}_{10}$, provided the effective killing of bacteria through the formation of ROS and $\mathrm{Zn}^{++}$. The results concluded that the potentially key factor of the anti-microbial activity in the NR films was the surface area and degree of dispersion of $\mathrm{ZnO}_{\mathrm{ws}}$ and $\mathrm{ZnO}_{\mathrm{np}}$ with and without modification. It was observed that the optimal degree of anti-microbial activity could be achieved by using $\mathrm{ZnO}$ of less purity, while the other properties were found to be maximized. The current study based on the film processing and $\mathrm{ZnO}_{\mathrm{np}}$ modification was highly beneficial to the NR film industries by improving the anti-microbial activity of the material together with better mechanical properties and cost-effectiveness, particularly in the case of NR gloves and medical NR-coated textiles. Upon the modification of $\mathrm{ZnO}$ with $\mathrm{CaCO}_{3}$, dispersion of $\mathrm{ZnO}_{\mathrm{np}}$ was effectively improved even though it has less purity. This is due to the high specific surface area of $\mathrm{ZnO}_{\mathrm{np}}$, which stimulates crosslinking of NR molecular chains and improves the anti-microbial properties. Less usage of $\mathrm{ZnO}$ in NR film is also important for minimizing the environmental pollution based on the decomposition of NR products since $\mathrm{ZnO}$ is considered a toxic constituent, particularly to aquatic organisms.

\section{Acknowledgements}

This research project is supported by Thailand Science Research and Innovation (TSRI), Basic Research Fund: Fiscal year 2021 under project number 64A306000052. Also, the support from the Program Management Unit for Human Resources \& Institutional Development, Research and Innovation [grant number B01F630003]. In addition, the King Mongkut's University and Technology Thonburi and Dr. Tanit Chavalit is acknowledged for their technical supporting.

\section{References}

[1] Le H., Abhijeet S., Ilisch S., Klehm J., Henning S., Beiner M., Sarkawi S. S., Dierkes W., Das A., Fischer D., Stöckelhuber K-W., Wiessnerah S., Khatiwadai S. P., Adhikarii R., Phamj T., Heinrichah G., Radusch H-J.: The role of linked phospholipids in the rubber-filler interaction in carbon nanotube (CNT) filled natural rubber (NR) composites. Polymer, 55, 4738-4747 (2014). https://doi.org/10.1016/j.polymer.2014.07.043

[2] Krainoi A., Kummerlöwe C., Nakaramontri Y., Vennemann N., Pichaiyut S., Wisunthorn S., Nakason C.: Influence of critical carbon nanotube loading on mechanical and electrical properties of epoxidized natural rubber nanocomposites. Polymer Testing, 66, 122-136 (2018).

https://doi.org/10.1016/j.polymertesting.2018.01.003

[3] Yang D., Ni Y., Liang Y., Li B., Ma H., Zhang L.: Improved thermal conductivity and electromechanical properties of natural rubber by constructing $\mathrm{Al}_{2} \mathrm{O}_{3}$ PDA-Ag hybrid nanoparticles. Composites Science and Technology, 180, 86-93 (2019).

https://doi.org/10.1016/j.compscitech.2019.05.019

[4] Nakaramontri Y., Pichaiyut S., Wisunthorn S., Nakason C.: Hybrid carbon nanotubes and conductive carbon black in natural rubber composites to enhance electrical conductivity by reducing gaps separating carbon nanotube encapsulates. European Polymer Journal, 90, 467484 (2017).

https://doi.org/10.1016/j.eurpolymj.2017.03.029

[5] Nakaramontri Y., Kummerlöwe C., Vennemann N., Wisunthorn S., Pichaiyut S., Nakason C.: Electron tunneling in carbon nanotubes and carbon black hybrid filler-filled natural rubber composites: Influence of nonrubber components. Polymer Composites, 39, 12371250 (2018).

https://doi.org/10.1002/pc.24821

[6] Hess W. M., Klamp W. K.: The effects of carbon black and other compounding variables on tire rolling resistance and traction. Rubber Chemistry and Technology, 56, 390-417 (1983).

https://doi.org/10.5254/1.3538134

[7] Martin P. J., Brown P., Chapman A. V., Cook S.: Silica-reinforced epoxidized natural rubber tire treads Performance and durability. Rubber Chemistry and Technology, 88, 390-411 (2015). https://doi.org/10.5254/rct.15.85940

[8] Sattayanurak S., Sahakaro K., Kaewsakul W., Dierkes W. K., Reuvekamp L. A., Blume A., Noordermeer J. W.: Synergistic effect by high specific surface area carbon black as secondary filler in silica reinforced natural rubber tire tread compounds. Polymer Testing, 81, 106173/1-106173/10 (2020).

https://doi.org/10.1016/j.polymertesting.2019.106173 
[9] Sarkawi S. S., Aziz A. K. C., Rahim R. A., Ghani R. A., Kamaruddin A. N.: Properties of epoxidized natural rubber tread compound: The hybrid reinforcing effect of silica and silane system. Polymers and Polymer Composites, 24, 775-782 (2016).

https://doi.org/10.1177/096739111602400914

[10] Wang P., Tan K. L., Ho C. C., Khew M. C., Kang E. T.: Surface modification of natural rubber latex films by graft copolymerization. European Polymer Journal, 36, 1323-1331 (2000).

https://doi.org/10.1016/S0014-3057(99)00193-7

[11] Wongthong P., Nakason C., Pan Q., Rempel G. L., Kiatkamjornwong S.: Modification of deproteinized natural rubber via grafting polymerization with maleic anhydride. European Polymer Journal, 49, 4035-4046 (2013).

https://doi.org/10.1016/j.eurpolymj.2013.09.009

[12] Sondi I., Salopek-Sondi B.: Silver nanoparticles as antimicrobial agent: A case study on E. coli as a model for gram-negative bacteria. Journal of Colloid and Interface Science, 275, 177-182 (2004).

https://doi.org/10.1016/j.jcis.2004.02.012

[13] Silvestry-Rodriguez N., Sicairos-Ruelas E. E., Gerba C. P., Bright K. R.: Silver as a disinfectant. in 'Reviews of environmental contamination and toxicology' (ed.: Ware G.) Springer, New York, 23-45 (2007). https://doi.org/10.1007/978-0-387-69163-3_2

[14] Singh G., Patankar R. B., Gupta V. K.: The preparation of polymer/silver nanocomposites and application as an antibacterial material. Polymer-Plastics Technology and Engineering, 49, 1329-1333 (2010). https://doi.org/10.1080/03602559.2010.496428

[15] Fu G., Vary P. S., Lin C-T.: Anatase $\mathrm{TiO}_{2}$ nanocomposites for antimicrobial coatings. The Journal of Physical Chemistry B, 109, 8889-8898 (2005).

https://doi.org/10.1021/jp0502196

[16] Liu Y., Wang X., Yang F., Yang X.: Excellent antimicrobial properties of mesoporous anatase $\mathrm{TiO}_{2}$ and $\mathrm{Ag} /$ $\mathrm{TiO}_{2}$ composite films. Microporous and Mesoporous Materials, 114, 431-439 (2008).

https://doi.org/10.1016/j.micromeso.2008.01.032

[17] Padmavathy N., Vijayaraghavan R.: Enhanced bioactivity of $\mathrm{ZnO}$ nanoparticles-an antimicrobial study. Science and Technology of Advanced Materials, 9, 035004/1-035004/7 (2008).

https://doi.org/10.1088/1468-6996/9/3/035004

[18] Tam K. H., Djurišić A. B., Chan C. M. N., Xi Y. Y., Tse C. W., Leung Y. H., Chan W. K., Leung F. C. C., Au D. W. T.: Antibacterial activity of $\mathrm{ZnO}$ nanorods prepared by a hydrothermal method. Thin Solid Films, 516, 6167-6174 (2008).

https://doi.org/10.1016/j.tsf.2007.11.081

[19] Li X., Xing Y., Jiang Y., Ding Y., Li W.: Antimicrobial activities of $\mathrm{ZnO}$ powder-coated PVC film to inactivate food pathogens. International Journal of Food Science and Technology, 44, 2161-2168 (2009). https://doi.org/10.1111/j.1365-2621.2009.02055.x
[20] Jones N., Ray B., Ranjit K. T., Manna A. C.: Antibacterial activity of $\mathrm{ZnO}$ nanoparticle suspensions on a broad spectrum of microorganisms. Federation of European Microbiological Societies: Microbiology Letters, 279, 71-76 (2008). https://doi.org/10.1111/j.1574-6968.2007.01012.x

[21] Zhang L., Jiang Y., Ding Y., Daskalakis N., Jeuken L., Povey M., O’Neill A. J., York D. W.: Mechanistic investigation into antibacterial behaviour of suspensions of $\mathrm{ZnO}$ nanoparticles against $E$. coli. Journal of Nanoparticle Research, 12, 1625-1636 (2010).

https://doi.org/10.1007/s11051-009-9711-1

[22] Tayel A. A., El-Tras W. F., Moussa S., El-Baz A. F., Mahrous H., Salem M. F., Brimer L.: Antibacterial action of zinc oxide nanoparticles against foodborne pathogens. Journal of Food Safety, 31, 211-218 (2011). https://doi.org/10.1111/j.1745-4565.2010.00287.x

[23] Jo Y., Garcia C. V., Ko S., Lee W., Shin G. H., Choi J. C., Park S-J., Kim J. T.: Characterization and antibacterial properties of nanosilver-applied polyethylene and polypropylene composite films for food packaging applications. Food Bioscience, 23, 83-90 (2018).

https://doi.org/10.1016/j.fbio.2018.03.008

[24] Andrade P. F., de Faria A. F., Oliveira S. R., Arruda M. A. Z., do Carmo Gonçalves M.: Improved antibacterial activity of nanofiltration polysulfone membranes modified with silver nanoparticles. Water Research, 81, 333-342 (2015). https://doi.org/10.1016/j.watres.2015.05.006

[25] Yu Z., Wang W., Kong F., Lin M., Mustapha A.: Cellulose nanofibril/silver nanoparticle composite as an active food packaging system and its toxicity to human colon cells. International Journal of Biological Macromolecules, 129, 887-894 (2019).

https://doi.org/10.1016/j.ijbiomac.2019.02.084

[26] Choi O., Hu Z.: Size dependent and reactive oxygen species related nanosilver toxicity to nitrifying bacteria. Environmental Science and Technology, 42, 4583-4588 (2008).

https://doi.org/10.1021/es703238h

[27] Siddiqi K. S., Rahman A., Tajuddin, Husen A.: Properties of zinc oxide nanoparticles and their activity against microbes. Nanoscale Research Letters, 13, 141/1-141/13 (2018). https://doi.org/10.1186/s11671-018-2532-3

[28] Ponnamma D., Cabibihan J-J., Rajan M., Pethaiah S. S., Deshmukh K., Gogoi J. P., Pasha S. K., Ahamed M. B., Krishnegowda J., Chandrashekar B., Polu A. R., Cheng C.: Synthesis, optimization and applications of $\mathrm{ZnO}$ /polymer nanocomposites. Materials Science and Engineering: C, 98, 1210-1240 (2019). https://doi.org/10.1016/j.msec.2019.01.081

[29] Díez-Pascual A. M., Díez-Vicente A. L.: Development of nanocomposites reinforced with carboxylated poly (ether ether ketone) grafted to zinc oxide with superior antibacterial properties. ACS Applied Materials and Interfaces, 6, 3729-3741 (2014).

https://doi.org/10.1021/am500171x 
[30] Rathnayake W., Ismail H., Baharin A., Bandara I., Rajapakse S.: Enhancement of the antibacterial activity of natural rubber latex foam by the incorporation of zinc oxide nanoparticles. Journal of Applied Polymer Science, 131, 39601-39610 (2014).

https://doi.org/10.1002/app.39601

[31] Anand K., Varghese S., Kurian T.: Effect of micro and nano zinc oxide on the properties of pre-vulcanized natural rubber latex films. Progress in Rubber Plastics and Recycling Technology, 31, 145-156 (2015). https://doi.org/10.1177/147776061503100301

[32] Lee Y. H., Cho M., Nam J-D., Lee Y.: Effect of ZnO particle sizes on thermal aging behavior of natural rubber vulcanizates. Polymer Degradation and Stability, 148, 50-55 (2018).

https://doi.org/10.1016/j.polymdegradstab.2018.01.004

[33] Hong R., Pan T., Qian J., Li H.: Synthesis and surface modification of $\mathrm{ZnO}$ nanoparticles. Chemical Engineering Journal, 119, 71-81 (2006).

https://doi.org/10.1016/j.cej.2006.03.003

[34] Preis W., Gamsjäger H.: (Solid + solute) phase equilibria in aqueous solution. XIII. Thermodynamic properties of hydrozincite and predominance diagrams for $\left(\mathrm{Zn}^{2+}+\mathrm{H}_{2} \mathrm{O}+\mathrm{CO}_{2}\right)$. The Journal of Chemical Thermodynamics, 33, 803-819 (2001).

https://doi.org/10.1006/jcht.2000.0794

[35] Flory P. J., Rehner J.: Statistical mechanics of crosslinked polymer networks I. Rubberlike elasticity. The Journal of Chemical Physics, 11, 512-520 (1943). https://doi.org/10.1063/1.1723791

[36] Flory P. J.: Molecular size distribution in three dimensional polymers. I. Gelation. Journal of the American Chemical Society, 63, 3091-3096 (1941).

https://doi.org/10.1021/ja01856a061

[37] Nakaramontri Y., Nakason C., Kummerlöwe C., Vennemann N.: Influence of modified natural rubber on properties of natural rubber-carbon nanotube composites. Rubber Chemistry and Technology, 88, 199-218 (2015).

https://doi.org/10.5254/rct.14.85949

[38] Luo Y., Zhao R., Pendry J. B.: Van der Waals interactions at the nanoscale: The effects of nonlocality. Proceedings of the National Academy of Sciences, 111, 18422-18427 (2014).

https://doi.org/10.1073/pnas.1420551111

[39] Bhattacharyya S., Sinturel C., Bahloul O., Saboungi M-L., Thomas S., Salvetat J-P.: Improving reinforcement of natural rubber by networking of activated carbon nanotubes. Carbon, 46, 1037-1045 (2008).

https://doi.org/10.1016/j.carbon.2008.03.011

[40] Ding R., Leonov A.: A kinetic model for sulfur accelerated vulcanization of a natural rubber compound. Journal of Applied Polymer Science, 61, 455-463 (1996).

https://doi.org/10.1002/(SICI)1097-

4628(19960718)61:3<455::AID-APP8>3.0.CO;2-H
[41] Moezzi A., Mcdonagh A. M., Cortie M. B.: Zinc oxide particles: Synthesis, properties and applications. Chemical Engineering Journal, 185, 1-22 (2012).

https://doi.org/10.1016/j.cej.2012.01.076

[42] Krainoi A., Kummerlöwe C., Nakaramontri Y., Wisunthorn S., Vennemann N., Pichaiyut S., Kiatkamjornwong S., Nakason C.: Influence of carbon nanotube and ionic liquid on properties of natural rubber nanocomposites. Express Polymer Letters, 13, 327348 (2019).

https://doi.org/10.3144/expresspolymlett.2019.28

[43] Nakaramontri Y., Nakason C., Kummerlöwe C., Vennemann N.: Enhancement of electrical conductivity and filler dispersion of carbon nanotube filled natural rubber composites by latex mixing and in situ silanization. Rubber Chemistry and Technology, 89, 272-291 (2016).

https://doi.org/10.5254/rct.15.84848

[44] Yangthong H., Pichaiyut S., Wisunthorn S., Kummerlöwe C., Vennemann N., Nakason C.: Role of geopolymer as a cure activator in sulfur vulcanization of epoxidized natural rubber. Journal of Applied Polymer Science, 137, 48624-48638 (2020).

https://doi.org/10.1002/app.48624

[45] Tolera M., Abate D., Dheresa M., Marami D.: Bacterial nosocomial infections and antimicrobial susceptibility pattern among patients admitted at Hiwot Fana Specialized University Hospital, eastern Ethiopia. Advances in Medicine, 2018, 2127814/1-2127814/7 (2018). https://doi.org/10.1155/2018/2127814

[46] Bidet P., Metais A., Mahjoub-Messai F., Durand L., Dehem M., Aujard Y., Bingen E., Nassif X., Bonacorsi S.: Detection and identification by PCR of a highly virulent phylogenetic subgroup among extraintestinal pathogenic Escherichia coli B2 strains. Applied and Environmental Microbiology, 73, 2373-2377 (2007).

https://doi.org/10.1128/AEM.02341-06

[47] Bodilsen J., Brouwer M. C., Kjærgaard N., Sirks M. J., van der Ende A., Nielsen H., van de Beek D.: Community-acquired meningitis in adults caused by Escherichia coli in Denmark and the Netherlands. Journal of Infection, 77, 25-29 (2018).

https://doi.org/10.1016/j.jinf.2018.05.009

[48] Li Y., Zhang W., Niu J., Chen Y.: Mechanism of photogenerated reactive oxygen species and correlation with the antibacterial properties of engineered metal-oxide nanoparticles. ACS Nano, 6, 5164-5173 (2012).

https://doi.org/10.1021/nn300934k

[49] Bukowska B., Michalowicz J., Pieniazek D., Sicinska P., Duda W.: Superoxide dismutases and their inhibitors-the role in some diseases. Current Enzyme Inhibition, 2, 379-397 (2006).

https://doi.org/10.2174/157340806778699271

[50] Collin F.: Chemical basis of reactive oxygen species reactivity and involvement in neurodegenerative diseases. International Journal of Molecular Sciences, 20, 2407/1-2407/17 (2019).

https://doi.org/10.3390/ijms20102407 
[51] Wiesmann N., Tremel W., Brieger J.: Zinc oxide nanoparticles for therapeutic purposes in cancer medicine. Journal of Materials Chemistry B, 8, 4973-4989 (2020). https://doi.org/10.1039/D0TB00739K

[52] da Silva B. L., Abuçafy M. P., Manaia E. B., Oshiro J. A. O., Chiari-Andréo B. G., Pietro R. C. L. R., Chiavacci L. A.: Relationship between structure and antimicrobial activity of zinc oxide nanoparticles: An overview. International Journal of Nanomedicine, 14, 9395-9410 (2019). https://doi.org/10.2147/IJN.S216204

[53] Shaikh S., Nazam N., Rizvi S. M. D., Ahmad K., Baig M. H., Lee E. J., Choi I.: Mechanistic insights into the antimicrobial actions of metallic nanoparticles and their implications for multidrug resistance. International Journal of Molecular Sciences, 20, 2468/1-2468/15 (2019). https://doi.org/10.3390/ijms20102468

[54] d’Água R. B., Branquinho R., Duarte M. P., Maurício E., Fernando A. L., Martins R., Fortunato E.: Efficient coverage of $\mathrm{ZnO}$ nanoparticles on cotton fibres for antibacterial finishing using a rapid and low cost in situ synthesis. New Journal of Chemistry, 42, 1052-1060 (2018).

https://doi.org/10.1039/C7NJ03418K
[55] Murínová S., Dercová K.: Response mechanisms of bacterial degraders to environmental contaminants on the level of cell walls and cytoplasmic membrane. International Journal of Microbiology, 2014, 873081/1$873081 / 16$ (2014).

https://doi.org/10.1155/2014/873081

[56] Wang L., Hu C., Shao L. Q.: The antimicrobial activity of nanoparticles: Present situation and prospects for the future. International Journal of Nanomedicine, 12, 1227 1249 (2017). https://doi.org/10.2147/IJN.S121956

[57] Sirelkhatim A., Mahmud S., Seeni A., Kaus N. H. M., Ann L. C., Bakhori S. K. M., Hasan H., Mohamad D.: Review on zinc oxide nanoparticles: Antibacterial activity and toxicity mechanism. Nano-micro Letters, 7, 219-242 (2015). https://doi.org/10.1007/s40820-015-0040-x

[58] Nordin R., Latiff N., Yusof R., Nawawi W. I., Salihin M. Z., Ishak Z. A. M.: Effect of several commercial rubbers as substrates for zinc oxide in the photocatalytic degradation of methylene blue under visible irradiation. Express Polymer Letters, 14, 838-847 (2020). https://doi.org/10.3144/expresspolymlett.2020.69

[59] Wolff S., Wang M-J.: Filler-elastomer interactions. Part IV. The effect of the surface energies of fillers on elastomer reinforcement. Rubber Chemistry and Technology, 65, 329-342 (1992). https://doi.org/10.5254/1.3538615 